Библиография произведений Н.В. Гоголя и литературы о нем на русском языке. 2019

V.A. Voropaev (Moscow, Russia)

\title{
The Bibliography of N.V. Gogol's Works and Literature about Him in Russian. 2019
}

\section{ПРОИЗ В Е ДЕНИЯ}

В чем же наконец существо русской поэзии и в чем ее особенность. Изд. стереотип. М.: Книжный дом «ЛИБРОКОМ», 2011. 126 с.

[Статьи Гоголя, посвященные русской поэзии.]

Содерж.:

В чем же наконец существо русской поэзии и в чем ее особенность. С. 3-41.

О лиризме наших поэтов. С. 42-54.

Предметы для лирического поэта в нынешнее время. С. 55-58.

О поэзии Козлова. С. 59-61.

Борис Годунов. Поэма Пушкина. С. 62-66.

Несколько слов о Пушкине. С. 67-72.

О малороссийских песнях. С. 73-79.

О театре, об одностороннем взгляде на театр и вообще об односторонности. С. 80-89.

Учебная книга словесности для русского юношества. С. 90-109.

Об «Одиссее», переводимой Жуковским. С. 110-117.

О том, что такое слово. С. 118-121.

Мертвые души: [поэма]. М.: Эксмо, 2019. 320 с. - (Классика в школе).

Мертвые души: поэма. М.: Изд-во АСТ, 2019. 416 с. - (Лучшая мировая классика).

Мертвые души. Ревизор. Проза. М.: Эксмо, 2019. 1088 с. - (Великие книги). 3000 экз.

Нос / Ил. О. Корытова. М.: Книжная индустрия, 2019. 64 с.: ил.

Полное собрание сочинений в одном томе. М.: Эксмо, 2019. 612 с. - (Полное собрание сочинений).

Размышления о Божественной Литургии. 2-е изд. Минск: Белорусская Православная Церковь, [2019.] 128 с.

[Текст печатается по изд.: СПб.: Синодальная типография, 1894. 124 с. В современной редакции.] [Изд. 1-е: Минск, 2015.] 
Ревизор: комедия в пяти действиях / Вступ. статья В.А. Воропаева; коммент. И.А. Виноградова, В.А. Воропаева; худож. В. Бритвин. М.: Детская литература, 2019. 128 с.: ил. - (Школьная библиотека). 3000 экз.

Загл. вступ. статьи: Над чем смеялся Гоголь. О духовном смысле комедии «Ревизор». С. 5-20. Коммент. С. 120-126.

Рождественский ужин: рассказы и стихи: вдохновляющее чтение для всей семьи / Сост. А.Н. Логунов. М.: Никея, 2019. 442 с.

Из содерж.:

Ночь перед Рождеством. С. 32-105.

Святочные рассказы русских писателей / Сост. Т.В. Стрыгиной. М.: Никея, 2019. 432 с. - (Рождественский подарок).

Из содерж.: Ночь перед Рождеством. С. 87-156.

Тарас Бульба: [повести]. М.: Эксмо, 2019. 192 с. - (Классика в школе).

Содерж.: Заколдованное место; Тарас Бульба.

\section{ЛИТ Е РАТ У РА}

Абаджсян Л.Ю. Изучение повести Н.В. Гоголя «Шинель» в 11-м классе армянской школы // Вестник Российского нового университета. Серия Человек в современном мире. М., 2019. № 1. C. 84-90.

Акимов М.В. Женщины Гоголя и его искушения. М.: Изд-во Вече, 2019. 351 с. - (Сер. Любовные драмы).

Аксиологическое пространство русской словесности: традиции и перспективы изучения: Материалы международной научной конференции «Кусковские чтения. Аксиологическое пространство русской словесности: традиции и перспективы изучения» (Москва, 3-6 октября 2019 г. / Министерство культуры Российской Федерации, Московский гос. ин-т культуры, Российский научно-исследовательский институт культурного и природного наследия им. Д.С. Лихачева; редкол.: И.В. Дергачева, А.Н. Ужанков; сост. М.В. Михайлова. М.: Издательский центр МГИК, 2019. 924 с.

Из содерж::

Федорова А.В. Образ Рима в поэзии С.П. Шевырева. С. 349-354.

[В частности, Римская тема у Гоголя.]

Шустова Д.Ю. Сравнение значимых составляющих словесной композиции повестей «Вий» Н.В. Гоголя и «Гробовщик» А.С. Пушкина. С. 765-773.

[Образ рассказчика у Гоголя и А.С. Пушкина.]

Андрущенко Е.Ю. Мюзикл и рок-опера на рубеже XX-XXI столетий: взаимодействия и диалоги // Проблемы музыкальной науки. Уфа, 2019. № 3(36). С. 122-129.

[В частности, о лайт-опере Александра Пантыкина «Гоголь. Чичиков. Души».]

Андрющенко М.В. Граница или «безграничие»: к вопросу хронотопа «проклятого» места в повести Н.В. Гоголя «Сорочинская ярмарка» // Международный журнал гуманитарных и естественных наук. Новосибирск, 2019. № 8-2. С. 46-49.

DOI: $10.24411 / 2500-1000-2019-11488$

Андрюшенко М.В. Образы-символы инфернального пространства и времени в повести Н.В. Гоголя «Майская ночь, или Утопленница» // International Journal of Advanced Studies in Language and Communication. 2019. № 1. C. 4-10.

Анисимов А.А. Лексические средства создания портрета в повести Н.В. Гоголя «Иван Федорович Шпонька и его тетушка» // Русский язык и литература: актуальные проблемы теории и практики преподавания: сб. материалов IV всероссийской научно-методической конференции (Коломна, 26 марта 2019 г.) / Гос. социально-гуманитарный ун-т; под ред. М.А. Дубовой, Т.А. Капыриной. Коломна, 2019. С. 146-150. 
Анненкова Е.И. «Поэт» и «церковный пастырь» в контексте «Выбранных мест из переписки с друзьями» Н.В. Гоголя. Религиозно-эстетические аспекты русской литературы как методическая проблема // Известия Российского гос. педагогического ун-та им. А.И. Герцена. СПб., 2019. № 191. С. 117-129.

Анненкова Е.И. «Совместимо ли искусство и художественность с христианством...» (Размышления К.С. Аксакова и его современников // Русско-Византийский вестник. СПб., 2019. № 1(2). С. 322-345.

[«Выбранные места из переписки с друзьями» Гоголя в восприятии славянофилов.]

Антонова М.С. Запись Н.В. Гоголя в альбом И.П. Постникова: к проблемам атрибуции и интерпретации // Филология: научные исследования. М. 2019. № 2. С. 73-77.

Антонова М.С. Запись Н.В. Гоголя в альбом М.А. Власовой: к проблеме датировки // Litera. M. 2019. № 2. C. 31-36.

Афанасьева Ю.С. «Патриотизм лени»: актуальность современной действительности // Россия и мир: развитие цивилизаций. Трансформация политических ландшафтов за период 1999-2019 годы: Материалы IX международной научно-практической конференции (Москва, 3-4 апреля 2019 г.): В 2 ч. Ч. 2. М.: Институт мировых цивилизаций, 2019. С. 358-360. [В частности, понятие «патриотизм» в творчестве Гоголя.]

Бадахова Р.Я. Гоголевская традиция в поэтике художественной прозы Л.Н. Толстого // Вестник Чувашского гос. педагогического ун-та им. И.Я. Яковлева. Чебоксары, 2019. №4(104). C. 3-8.

DOI:10.26293/chgpu.2019.104.4.001

Баженова Е.В. Лингвоконцепт месяц в повестях «Вий» и «Портрет» Н.В. Гоголя // Русский язык: история, диалекты, современность: сб. научных статей по материалам докладов и сообщений конференции (Москва, 29 апреля 2019 г.) / Московский гос. областной ун-т; сост. Ю.В. Коренева, О.В. Ряховская; отв. ред. Л.Ф. Копосов. М., 2019. С. 16-20.

Баль В.Ю. Плюшкинский сюжет в романе О. Славниковой «Стрекоза, увеличенная до размеров собаки» // Вестник Томского гос. ун-та. Филология. Томск, 2019. № 60. С. 104-132.

$<$ Белинский В.Г.> В.Г. Белинский и русские писатели ХІХ века / Институт мировой литературы им. А.М. Горького РАН; отв. ред. А.С. Курилов. М.: Литературная Россия, 2019. 352 с. Из содерж::

Монахова И.Р. Белинский и Гоголь. Штрихи к двойному портрету. С. 25-65.

Монахова И.Р. «Противоборствовать без всякой вражды». В.Г. Белинский и К.С. Аксаков: полемика друзей-противников. С. 139-172.

Белова Т.Н. Постмодернистские аспекты художественного и литературно-критического наследия В.В. Набокова // Литературное зарубежье как культурный феномен: сб. научных трудов / Сер. Теория и история литературоведения РАН. ИНИОН. Центр гуманитарных научно-информационных исследований. Отдел литературоведения; отв. ред. Т.Г. Петрова; ред.-сост. К.А. Жулькова, Т.Г. Петрова. М., 2019. С. 77-104.

[В частности, об эссе В.В. Набокова «Николай Гоголь» (1944).]

Беляева T. Роль цветовой лексики в повестях Н.В. Гоголя // Русский язык в XXI веке: исследования молодых: Материалы VI международной научной студенческой конференции (Сургут, 7-8 февраля 2019 г.) / Сургутский гос. педагогический ун-т и др.; отв. ред. Е.А. Журавлева; отв. секретарь Э.Э. Яворская. Сургут, 2019. С. 27-30.

Блищ Н.Л. Литературная орнитология: Гоголь - Ремизов - Сирин - Соколов // Мир русскоговорящих стран / Ярославский гос. педагогический ун-т им. К.Д. Ушинского. Ярославль, 2019. № 1(1). С. 93-97.

[Орнитологические образы в творчестве русских писателей с «птичьими» фамилиями или псевдонимами. Утверждается, что А. Ремизов, В. Набоков (Сирин) и Саша Соколов наследуют го- 
голевские формы авторефлексии и используют связанные с миром птиц образы и ситуации как элементы символической тайнописи.]

Бондаренко М.А. Товар суровский, щепетильный, москательный, овошенный... // Русская речь. М., 2019. № 4. С. 67-76.

DOI: $10.31857 / \mathrm{S} 013161170005363-8$

[Анализ лексического значения и произношения слова «овошенный», которое встречается в художественных и деловых текстах XIX в., в том числе в комедии Гоголя «Ревизор».]

Бордуновский М. Авторские отступления в романе Н.Г. Чернышевского «Что делать?» в контексте произведений А.С. Пушкина и Н.В. Гоголя // Актуальная классика: Материалы Третьих студенческих научных чтений (Москва, 18 апреля 2019 г.). М.: Литера, 2019. C. $82-90$.

$<$ Брюсов В.> Валерий Брюсов - историк литературы: переписка с П.И. Бартеневым и Н.О. Лернером / Российская академия наук, Институт мировой литературы им. А.М. Горького; подгот. Н.А. Богомолов и А.В. Лавров (ред.). М.: Литфакт, 2019. 406, [1] с. - (Библиотека «Литературного наследства». Новая серия / Литературное наследство; вып. 5). 300 экз. [Указ. имен.]

Бузмакова А.Л. Образ врача в отечественной драматургии // Скиф. Вопросы студенческой науки. СПб., 2019. № 2(30). С. 37-39.

[В частности, доктор Гибнер в комедии Гоголя «Ревизор».]

Букреев А.М. Портрет как символ тщеславия в повести Н.В. Гоголя «Портрет» // Будущее науки - 2019: сб. научных статей 7-й международной молодежной научной конференции (Курск, 25-26 апреля 2019 г.). Т. 2: Гуманитарные науки / Юго-Западный гос. ун-т. Курск, 2019. C. 49-52.

$<$ Булгаков M.A.> М.А. Булгаков: pro et contra: личность и творчество М.А. Булгакова в оценках литературоведов, критиков, социологов, искусствоведов: антология / Русская христианская гуманитарная академия; сост. О.В. Богдановой. СПб: Изд-во РХГА, 2019. 992 с. - (Русский Путь).

[Указ. имен.]

$<$ Булгарин Ф.В.> Ф.В. Булгарин - писатель, журналист, театральный критик: сб. статей / Сост. А.И. Рейблат. М.: Новое литературное обозрение, 2019. 528 с. - (Серия Научная библиотека).

[По материалам конференции «Ф.В. Булгарин - писатель, журналист, театральный критик» (Москва, 30-31 октября 2017 г.), организованной редакцией журнала «Новое литературное обозрение» и Российской гос. библиотекой искусств.]

[В частности, Ф.В. Булгарин и Гоголь.]

Бурмистрова С.В. Функции апостольского текста в «Выбранных местах из переписки с друзьями» Н.В. Гоголя // Stephanos. М., 2019. № 3 (35). С. 99-107.

DOI 10.24249/2309-9917-2019-35-3-99-107

[В основу статьи положен доклад, прочитанный автором на всероссийской (с международным участием) научной конференции «Творческое наследие Н.В. Гоголя: история и современность. К 210-летию со дня рождения» (Москва, 1-2 апреля 2019 г.) / Московский гос. ун-т имени М.В. Ломоносова, филологического факультет.]

Бурцева Д.Р. Сравнительно-сопоставительный анализ образов скупцов в поэме «Мертвые души» Н.В. Гоголя и поэме «Скупой богач» А.Е. Кулаковского // МНСК-2019. Литературоведение: Материалы 57-й международной научной студенческой конференции (Новосибирск, 14-19 апреля 2019 г.) / Новосибирский национальный исследовательский гос. ун-т; гл. ред. О.А. Донских; отв. секретарь Т.В. Скрыпник. Новосибирск, 2019. С. 26-27.

Быков Д.Л. Русская литература: страсть и власть. М. Изд-во АСТ: Редакция Елены Шубиной, 2019. 573, [3] с. - (Прямая речь).

Николай Гоголь. 
«Тарас Бульба». С. 185-192.

«Вий» как русская эротическая утопия. С. 193-199.

В поисках второго тома. С. 200-216.

Ваулина С.С., Булатая E.B. Средства выражения иронии в немецкоязычных переводах гоголевских текстов // Научный диалог / Центр научных и образовательных проектов. Екатеринбург, 2019. №3. С. 9-23.

DOI: $10.24224 / 2227-1295-2019-3-9-23$

$<$ Варсонофий Оптинский, преп.> Не бойся, цел твой кораблик. Истории, рассказанные преподобным Варсонофием Оптинским / Сост. Г. Соколова. М.: Никея, 2019. 448 с.: ил. Все лучшие люди всегда стремились к Богу, источнику истины. С. 237-282.

Вошел я к старцу одним, вышел другим. С. 239-247.

[Гоголь в Оптиной пустыни.]

Взгляд на небо - это уже дело. С. 247-250.

[Гоголь и Псалтирь: С. 249-250.]

Великие люди о вере / Ред.-сост. Е. Зубкова. М.: Вольный Странник: Фонд социокультурных проектов «Традиция», 2019. 112 с.: цв. ил. 3000 экз.

Николай Васильевич Гоголь. С. 34-35.

Видугирите И. Гоголь и географическое воображение романтизма: монография. М.: Новое литературное обозрение, 2019. 320 с.: ил. - (Научная библиотека).

Викулова В.П. «Мой адрес: Москва, на Никитском бульваре в доме Талызина». Дом Гоголя в Москве // Литература в школе. М., 2019. №4. С. 22-23.

[Сведения о музее Гоголя в Москве, которые могут быть использованы на уроках литературы и в дополнительном образовании; освещен опыт работы музея: тематические экскурсии в «Доме Гоголя», интерактивные занятия, пешеходные экскурсии по гоголевским местам в Москве и др.]

Виноградов И.А. «Когда в товарищах согласья нет...» А.С. Пушкин, Н.В. Гоголь, С.С. Уваров // Два века русской классики: научный филологический журнал / ИМЛИ им. А.М. Горького РАН. М., 2019. № 1. С. 34-103.

DOI 10.22455/2686-7494-2019-1-1-34-103

Виноградов И.А. Знакомые Н.В. Гоголя в круге общения К. Маркса: к истории одного знакомства // Studia Litterarum / ИМЛИ им. А.М. Горького РАН. М., 2019. Т. 4. № 1. С. 236-249. DOI: $10.22455 / 2500-4247-2019-4-1-236-249$

Виноградов И. Иллюзия достоверности. Гоголевские «Игроки» - притча о современности // Литературная газета. М., 2019. 3 апреля. № 13(6685). С. 8.

Виноградов И.А. «Лишние люди» в русской литературе: слово Гоголя // Studia Litterarum / ИМЛИ им. А.М. Горького РАН. М., 2019. Т. 4. № 3. С. 188-209.

DOI: $10.22455 / 2500-4247-2019-4-3-188-209$

Виноградов И.А. «Лишние люди» русской литературы: новое в школьной теме // Stephanos. 2019. № 3(35). C. 108-120.

DOI 10.24249/2309-9917-2019-35-3-108-120

[В основу статьи положен доклад, прочитанный автором на всероссийской (с международным участием) научной конференции «Творческое наследие Н.В. Гоголя: история и современность. К 210-летию со дня рождения» (Москва, 1-2 апреля 2019 г.) / Московский гос. ун-т имени М.В. Ломоносова, филологический факультет.]

Виноградов И.А. Н.В. Гоголь в Одессе. Забытые свидетельства современников (письмо протоиерея Анатолия Корочанского и воспоминания Н.И. Савича) // Литературный факт: научный журнал. М.: ИМЛИ РАН, 2019. № 11. С. 403-415.

DOI 10.22455/2541-8297-2019-11-403-415

Виноградов И.А. Образ монарха-наставника в творчестве Н.В. Гоголя // Проблемы исторической поэтики. 2019. Т. 17. № 2. С. 111-134.

DOI: $10.15393 /$ j9.art.2019.6202 
Виноградов И.А. Феномен западничества в славянофильстве: взгляд Гоголя // Литературный факт: научный журнал. М.: ИМЛИ РАН, 2019. № 2(12). С. 189-224.

DOI: $10.22455 / 2541-8297-2019-12-189-224$

Виноградов И.А. Ю.Ф. Самарин как неизвестный адресат «Выбранных мест из переписки с друзьями» Н.В. Гоголя. К 200-летию мыслителя-славянофила // Вестник славянских культур. М, 2019. Т. 54. С. 197-212.

http://www.vestnik-sk.ru/russian/archive/2019/tom-54/vinogradov

Виноградов И.А. Эсхатология комедии Н.В. Гоголя «Ревизор» // Проблемы исторической поэтики. 2019. Т. 17. № 4. С. 68-90.

DOI: $10.15393 / \mathrm{j} 9$. art.2019.5801

Виноградов И.А. Эсхатология комедии Н.В. Гоголя «Ревизор» // Филология как призвание: сб. статей к юбилею проф. В.Н. Захарова / Петрозаводский гос. ун-т; отв. ред. А.В. Пигин, И.С. Андрианова. Петрозаводск: Изд-во ПетрГУ, 2019. С. 381-400.

Виролайнен М.Н. Брачный сюжет в гоголевском Петербурге // Новый филологический вестник. М., 2019. № 3(50). С. 44-52.

Владимиров Артемий, протоиерей. Души мертвые и живые / Вступ. слово В.А. Воропаева; худож. Татьяна Косач. М.: Антикъ, 2019. 48 с.: ил.

Загл. вступ. слова: «Нет другой двери...». С. 3.

[О героях «Мертвых душ» Гоголя.]

Воронский А. Гоголь / Вступ. статья В.А. Воропаева. М.: Молодая гвардия, 2019. 300 с. Загл. вступ. статьи: Забытая книга. Об Александре Воронском и его «Гоголе». С. 5-12.

Boponaев B. Апология России. Н.В. Гоголь: историк и политический мыслитель. К 210-летию со дня рождения // История: научно-методический журнал для учителей истории и обществознания. М, 2019. № 11-12(632). Ноябрь - Декабрь. С. 42-45.

Boponaев B.A. Библиография произведений Н.В. Гоголя и литературы о нем на русском языке (2017) // Stephanos. M., 2019. № 3(35). C. 175-217.

DOI: $10.24249 / 2309-9917-2019-35-3-175-217$

Bоропаев B.A. Библиография произведений Н.В. Гоголя и литературы о нем на русском языке (1917-1928) // Stephanos. M., 2019. № 5(37). C. 139-185.

DOI: $10.24249 / 2309-9917-2019-37-5-139-185$

Bоропаев B.A. В ожидании Ревизора. Гоголь и Евангелие // Уроки литературы. Приложение к журналу «Литература в школе». М., 2019. № 1. С. 1-5.

[Беседу вел Юрий Пущаев.]

Воропаев B. Всероссийская (с международным участием) научная конференции «Творческое наследие Н.В. Гоголя: история и современность. К 210 -летию со дня рождения» на филологическом факультете МГУ // Глаголица: [газета филологического факультета МГУ имени М.В. Ломоносова.] М., 2019. Май. С. 7.

Boponaев B.A. Где и когда родился Гоголь: возвращение к теме // Stephanos. M., 2019. № 3(35). C. 121-125.

DOI: $10.24249 / 2309-9917-2019-35-3-121-125$

[В основу статьи положен доклад, прочитанный автором на всероссийской (с международным участием) научной конференции «Творческое наследие Н.В. Гоголя: история и современность. К 210-летию со дня рождения» (Москва, 1-2 апреля 2019 г.) / Московский гос. ун-т имени М.В. Ломоносова, филологического факультет.]

Boponaев B.A. Гоголь как поэт: от романтической поэмы к жанру стихотворной молитвы // Поэзия филологии. Филология поэзии. Вып. 2: сб. [материалов] конференции, посвященной А.А. Илюшину / Московский гос. ун-т им. М.В. Ломоносова; ред.-сост. 
В.Б. Катаев, Е.А. Пастернак; под общ. ред. О.А. Кузнецовой, Е.А. Пастернак. Тверь: Издатель А.Н. Кондратьев, 2019. С. 98-104.

Boponaев B.A. Духовник Гоголя. Ч. 1: Иоанн Кронштадтский Ржевского уезда. Протоиерей Матфей Константиновский // Stephanos. М., 2019 № 1(33). С. 62-77.

DOI: 10.24249/2309-9917-2019-33-1-62-77.

Bоропаев B.A. Духовник Гоголя. Ч. 2: «Вам душа моя известна больше, чем мне самому». Гоголь и протоиерей Матфей Ржевский // Stephanos. М., 2019 № 2(34). С. 55-80.

DOI: $10.24249 / 2309-9917-2019-34-2-55-80$

Boponaев B.A. «Ей, гряди, Господи Иисусе»: Тайна смерти Н.В. Гоголя в свете его церковного мировоззрения // Русско-Византийский вестник: научный журнал / Санкт-Петербургская Духовная академия. СПб., 2019. № 1(2). С. 244-288.

Boponaев B.A. «Ей, гряди, Господи Иисусе»: Тайна смерти Н.В. Гоголя в свете его церковного мировоззрения. Ч. 1-2 // Русская народная линия. СПб., 2019. 17. 05 (www. ruskline.ru).

Boponaeв B.A. «Ей, гряди, Господи Иисусе»: Тайна смерти Н.В. Гоголя в свете его церковного мировоззрения. Ч. 3 // Русская народная линия. СПб., 2019. 20. 05 (www. ruskline.ru).

Boponaев B.A. «Ей, гряди, Господи Иисусе»: Тайна смерти Н.В. Гоголя в свете его церковного мировоззрения. Ч. 4-5 // Русская народная линия. СПб., 2019. 23 мая (www. ruskline.ru).

Boponaев B.A. «Ей, гряди, Господи Иисусе»: Тайна смерти Н.В. Гоголя в свете его церковного мировоззрения. Ч. 6-8 // Русская народная линия. СПб., 2019. 28 мая (www. ruskline.ru).

Boponaев B.A. «Ей, гряди, Господи Иисусе»: Тайна смерти Н.В. Гоголя в свете его церковного мировоззрения. Ч. 9-10 // Русская народная линия. СПб., 2019. 31 мая (www. ruskline.ru).

Bоропаев В. Когда родился Гоголь // Православное книжное обозрение. М., 2019. № 3(091). Март. С. 40-43.

Bоропаев B.A. Когда родился Гоголь? // Народный учитель: газета Московского гос. областного ун-та. М., 2019. № 3-4. Март - Апрель. С. 7.

Bоропаев B.A. Лествица, возводящая на небо. Православная аскетика в судьбе Гоголя // Православное книжное обозрение. М., 2019. № 1(89). С. 14-21.

Boponaeв B.A. «Лестницу поскорее, давай лестницу!..» О русском писателе Гоголе и Синайском игумене Иоанне // Православие.py. 2019. 5 мая (www.pravoslavie.ru).

[Беседовал Юрий Пущаев.]

Boponaев B. Народный поэт: Гоголь и Оптинские старцы о Крылове // Православное книжное обозрение. М., 2019. № 12(99). С. 48-55.

[К 250-летию со дня рождения.]

Bоропаев B.A. Нет другой двери...: О Гоголе и не только. М.: Белый город, 2019. 448 с.: ил. [Рец.: Умнягин В., иерей // Stephanos. М., 2019. № 6(38). С. 151-155.; Каплин А.Д. Христианин идет вперед... // Православное книжное обозрение. М., 2019. № 12(99). С. 56-62.]

Bоропаев B. Нужно любить Россию. Гоголь о патриотизме // Балашиха: Голоса сердец: литературно-публицистический журнал. Балашиха, 2019. № 2(49). С. 58-60. 
Boponaев B.A. Очерки о Николае Васильевиче Гоголе (1809-1852) // Московский журнал. Приложение: «Истинный ведатель сердца человеческого». К 210-летию со дня рождения Николая Васильевича Гоголя (1809-1852). М., 2019. 32 с.: ил.

Boponaев B.A. «Пророк православной культуры». Николай Васильевич Гоголь как мыслитель // Московский журнал. М., 2019. № 10(346). Октябрь. С. 72-77.

[К 210-летию со дня рождения.]

Boponaев B.A. Пророк православной культуры: Гоголь как мыслитель. К 210-летию со дня рождения // Православный собеседник: журнал Татарстанской митрополии. Казань, 2019. №2(13). С. 84-89.

Boponaев B. Родина Гоголя. К 210-летию со дня рождения // Православная беседа. М., 2019. № 2. C. 72-77.

Boponaев B.A. «Ум безоговорочный»: Гоголь о Крылове // Русская словесность. М., 2019. №4. C. 7-14.

Boponaев B.A. «Церковь одна». А.С. Хомяков и Н.В. Гоголь о единстве Церкви // К единству! Журнал Международного общественного Фонда единства православных народов. М., 2019. №3(126). С. 30-32.

Boponaев B.A. «Церковь одна». А.С. Хомяков и Н.В. Гоголь о единстве Церкви // Русская народная линия. СПб., 2019. 05. 07 (www.ruskline.ru).

[К 210-летию со дня рождения Н.В. Гоголя и 215 -летию со дня рождения А.С. Хомякова.]

Восток - Запад: пространство локального текста в литературе и фольклоре: сб. научных статей к 70-летию проф. А.Х. Гольденберга / Министерство науки и высшего образования Российской Федерации; Волгоградский гос. социально-педагогический ун-т; отв. ред. Н.Е. Тропкина. Волгоград: Научное издательство ВГСПУ «Перемена», 2019. 471 с.

[Материалы VIII международной научной конференции «Восток - Запад: пространство локального текста в литературе и фольклоре. К 70-летию профессора А.Х. Гольденберга» (Волгоград, $27-28$ ноября 2018 г.).]

Из содерж.:

Раздел 2: Локальные тексты в художественном пространстве Гоголя

Boponaев B.A. Гоголь и преподобный Макарий Оптинский: из истории взаимоотношений. C. 66-72.

Гуминский В.М. К проблеме пространства у Гоголя. С. 73-78.

Денисов В.Д. Пространственные модели и образы в повести Н.В. Гоголя «Старосветские помещики». С. 79-87.

Падерина Е.Г. Пародийный провинциальный сюжет в прозе («Коляска») и комедии («Игроки»). C. 87-94.

Гольденберг А.X. «Царицынский текст» в творческом наследии Гоголя. С. 94-104.

Попович T. Герои-двойники в двойном пространстве Гоголя и в художественном мире его сербских последователей. С. 104-110.

Шульи С.A. «Вий» Гоголя и комические произведения Г. Сакса. С. 110-116.

Завьялова Е.Е. Образ пространства в пьесе О.А. Богаева «Башмачкин». С. 116-123.

Вранчан Е.В. Гоголевская Россия и русская революция // Февраль 1917-го: уроки прошлого: Материалы межвузовской научной конференции (Новосибирск, 17 февраля 2017 г.) / Новосибирский гос. ун-т экономики и управления; отв. ред. Д.М. Шиловский. Новосибирск, 2019. С. 41-52.

[Феномен русской революции в осмыслении Н.А. Бердяева, указавшем на возможность разгадки последствий революционных событий в русской литературе, в первую очередь в художественных образах Гоголя.] 
Гаврилов И.Б. Вопросы просвещения и образования в русской религиозной мысли второй четверти XIX в. // Христианское чтение / Санкт-Петербургская Духовная академия. СПб., 2020. № 2. С. 153-177.

[В частности, философско-педагогические воззрения Гоголя.]

Гаврильченко О.В. «И глазам офицеров предстал Чертокуцкий...»: из истории иллюстрирования повести Н.В. Гоголя «Коляска» // Филологические науки. Вопросы теории и практики. Тамбов: Грамота, 2019. Т. 12. № 12. С. 7-11.

DOI: 10.30853/filnauki.2019.12.1

[Обзор иллюстрированных изданий повести Гоголя «Коляска».]

Галкина В.В. «Собачье сердце» и «Шинель» итальянского режиссера А. Латтуада // Кино. Речь. Культура: Материалы международного студенческого форума (Санкт-Петербург, 25-26 мая 2018 г.) / Санкт-Петербургский гос. ин-т кино и телевидения; отв. ред. Е.И. Лелис. СПб., 2019. С. 82-87.

[Анализ кинофильмов итальянского режиссера А. Латтуада, снятых по мотивам произведений М.А. Булгакова и Гоголя.]

Гиматутдинова Ю.А., Ковалева Н.А. Мистические тайны Гоголя // Научно-технические достижения студентов, аспирантов, молодых ученых строительно-архитектурной отрасли: сб. научных трудов $\mathrm{V}$ республиканской конференции молодых ученых, аспирантов, студентов. (Макеевка, 19 апреля 2019 г.). Т. 3: Гуманитарные науки / Донбасская национальная академия строительства и архитектуры. Макеевка, 2019. С. 158-162.

Гоголезнавчі студії=Гоголеведческие студии / Редкол.: П.В. Михед (відп. ред.), О.Г. Ковальчук, С.Д. Абрамович, В.О. Воропаев [та ін.]; Ніжинський держ. ун-т ім. М. Гоголя; Гоголезнавчий центр; Інститут літератури ім. Т.Г. Шевченка НАН України. Вип. 8(25). Ніжин: ФОП Лук'яненко В.В. ТПК «Орхідея», 2019. 458 с. - (Сер. «Гоголезнавчі студії»). На рус. и укр. яз.

[Вип. присвячено 70-літтю від дня народження доктора філологічних наук, проф. П.В. Михеда.] Из содерж.:

Абрамович С.Д. Поприще безумия и его сотериологическая проекция (еще раз о «Записках сумасшедшего»). С. 5-18.

Виноградов И.А. «Она ворочает вкусами целых толп...» Гоголь и журналистика 1820-х - 1840-х гг. C. $19-106$.

Дикарева Л.Ю. Аналогия как способ объективации идеи превращения в художественной речи Н.В. Гоголя. С. 126-137.

Звиняиковский В.Я. Бешеная история (Киев в «Миргороде» и «Арабесках»). С. 138-151.

Кривонос В.Ш. И.А. Бунин, И.И. Ясинский и «анекдот о Гоголе». С. 167-183.

Морева Т.Ю. Межтекстовые связи в «Вечерах на хуторе близ Диканьки» Н.В. Гоголя. С. 184-195.

Мусий В.Б. Художественное время в петербургских повестях Н.В. Гоголя. С. 196-211.

Шульи С.А. Гоголь и Ганс Сакс. С. 224-235.

\section{Ювілеї}

Павло Володимирович Михед: до 70-річчя від дня народження (бібліографія) / Упоряд.: О.Д. Кільдіватова, В.І. Манжай, Н.В. Мухомодєєва; відп. ред. О.С. Морозов. С. 299-365. На рус. и укр. яз.

\section{Бібліографія}

Библиография произведений Н.В. Гоголя и литературы о нем на русском языке (2017). Подгот. В.А. Воропаев. С. 364-422.

Список авторефератов диссертаций, посвященных творчеству Н.В. Гоголя (2017). Подгот. В.А. Воропаев. С. 423.

Бібліографія України про життя і творчість Миколи Гоголя (2017). Підгот.: П.В. Михед, О.О. Костенко. С. 424-435. На рус. и укр. яз.

Зміст попередніх випусків «Гоголезнавчих студій». С. 436-457.

$<$ Гоголь Н.В.> Гоголь и пути развития русской литературы. К 200-летию И.С. Тургенева: Восемнадцатые Гоголевские чтения: сб. научных статей по материалам международной научной конференции, Москва, 1-3 апреля 2018 г. / Департамент культуры 
г. Москвы; «Дом Н.В. Гоголя - мемориальный музей и научная библиотека; под общ. ред. В.П. Викуловой. М.; Новосибирск: Новосибирский издательский дом, 2019. 256 с.: ил.

\section{Содерж.:}

Summary. C. 8-14.

Викулова В.П. Предисловие. С. 15-16.

Творчество Гоголя и развитие русской литературы:

Манн Ю.В. Поэтика Гоголя как предвестие модернизма (заметки). С. 18-23.

Воропаев В.А. Н.В. Гоголь и духовные писатели его времени. С. 24-34.

Виноградов И.А. Н.В. Гоголь и последующая литература: pro et contra. С. 35-42.

Гуминский В.М. Гоголь и «Вехи». С. 43-51.

Гольденберг А.X. «Лицом к России» (К творческой истории поздних замыслов Гоголя). С. 52-58.

Гоголь в кругу современников. «Гоголевский период» в русской литературе:

Анненкова Е.И. Гоголь и Иван Аксаков: «беспрерывная внутренняя переработка» как фактор творчества. С. 60-68.

Байич Лиляна. Повесть Гоголя «Шинель» и маленький человек в русской литературе XIX века. C. 69-73.

Кораблев А.А. Манифестация «гоголевского направления» в поэме «Мертвые души»: восточники и западники. С. 74-81.

Вранеш Александра, Маркович Лиляна. Гоголь и Тургенев в сербской периодике. С. 82-90.

Сартаков Е.В. Гоголь и «гоголевский период» в русской и сербской литературе. С. 91-95.

Джафарова К.К. Жанр повести в «Учебной книге словесности для русского юношества» Н.В. Гоголя. С. $96-101$.

Маливанова Е.И. П.В. Хавский - современник и московский сосед Н.В. Гоголя. С. 102-106.

Гоголь и Тургенев:

Сапченко Л.А. Русский помещик Лаврецкий. С. 108-114.

Савинков С.B. Смерть Гоголя в тургеневской рецепции: соблазн предположения. С. 115-117.

Иваниикий А.И. Место и роль волшебно-сказочного мира в народном сознании. «Вий» Н.В. Гоголя и «Бежин луг» И.С. Тургенева. С. 118-123.

Сугай Л.А. Гоголь и Тургенев в литературно-критических воззрениях символистов. С. 124-131.

Рипинская Е.В. Почему Райский не написал роман? (Образ художника у Гончарова). С. 132-145.

[Образ художника в романе И.А. Гончарова «Обрыв» и «Авторская исповедь» Гоголя.]

Шульи С. А. Метасюжет о «Мертвой красавице» / «Мертвой невесте»: от романтизма к постромантизму (Жуковский, Пушкин, Гоголь, Тургенев). С. 146-153.

Рясов Д.Л. Образы немцев в творчестве Н.В. Гоголя и И.С. Тургенева: продолжение литературной традиции. С. 154-160.

Высоикая В.В. Символика двойственности в художественном тексте (на материале произведений Гоголя и Тургенева). С. 161-168.

Влияние Гоголя на формирование реализма и модернизма:

Капустин Н.В. А.П. Чехов о (в) гоголевской «Коляске». С. 170-175.

Нагина К.А. От Н.В. Гоголя к Л.Н. Толстому: метаморфозы «дома» в пространстве русской литературы. С. 176-182.

Попович Таня М. «Сны и предсонье»: дискурсы бессознательного у Н.В. Гоголя и А.М. Ремизова. С. $183-190$.

Есаулов И.А. Гоголь и Розанов: проблемное поле в свете судьбы России. С. 191-196.

Балакиина Ю.В. Личность и творчество Гоголя в церковной рецепции начала ХХ века. С. 197-204. Кривонос В.Ш. Город в романе Ф. Сологуба «Мелкий бес»: гоголевский ракурс. С. 205-212.

Яблоков Е.A. «Лысый появился» (Гоголевский подтекст в повести М.А. Булгакова «Дьяволиада»). С. 213-220.

Иваньшина Е.A. О ревизорах и хлестаковщине в драматургии М.А. Булгакова. С. 221-227.

Швецова Т.С. Семантика путешествия в творческой биографии Н.В. Гоголя. С. 228-232.

Гоголь и современная русская литература:

Волоконская Т.А. Гоголевские мотивы в романе Альвдис Н. Рутиэн «Некоронованный». С. 234-240. Плешкова О.И. Традиции волшебной сказки и творчества Н.В. Гоголя в рассказе А. Битова «Нога»: к проблеме литературной эволюции. С. 241-245. 
Захаров К.М., Волоконская Т.А., Рясов Д.Л. Двадцать лет хлестаковщины: Хлестаковский фестиваль в Саратовском университете. С. 246-249.

Сведения об авторах. С. 250-255.

Гоголь // Родина: исторический научно-популярный журнал. М., 2019. № 4. С. 4-5.

$<$ Гоголь Н.В.> Н.В. Гоголь: Материалы и исследования: Вып. 4: К юбилею главного редактора Полного собрания сочинений и писем Н.В. Гоголя Ю.В. Манна / Российская академия наук. Институт мировой литературы им. А.М. Горького; редкол.: Е.И. Анненкова, Ю.В. Балакшина и др.; отв. ред. Н.Л. Виноградская, Е.Г. Падерина. М.: ИМЛИ РАН, 2019. 408 с. 500 экз.

Содерж.:

От редакции. С. 5-6.

Статьи. Комментарии:

Карташова И.В. О духовной драме позднего Гоголя в контексте эволюции романтического сознания (постановка вопроса). С. 9-20.

Анненкова Е.И. От писем к «Выбранным местам...». С. 21-37.

Балакшина Ю.В. Эпистолярное наследие Гоголя как источник «Выбранных мест из переписки с друзьями». С. $38-48$.

Зайчева И.А. Письмо Гоголя родителям от августа 1822 года (история публикации, судьба автографа, источники текста). С. 49-62.

Дерюгина Л.В. «Также вы писали про одну новую Балладу...». С. 63-86.

Виноградская Н.Л. Из истории театральных постановок «Носа». С 87-105.

Греков В.Н. «Китайские тени» комедии «Женитьба»: авторский замысел и сценическая интерпретация. С. 106-132.

Печерская Т.И. «Слоговые ходы Гоголя» в «Двойнике» Достоевского: анонимное цитирование как составляющая повествовательного кода. С. 133-148.

Архивные разыскания:

Виноградская Н.Л., Зайцева И.А. «Я стараюсь как можно успевать в науках...» (Письма М.В. Гоголь-Яновской 1820-х гг.) / Вступ. статья, подгот. текстов, текстологический и палеографический коммент, а также реальный коммент. к письмам М.В. Гоголь 1824-1826 гг. - Н.Л. Виноградской; публ. и реальный коммент. к письмам 1827-1828 гг. - И.А. Зайцевой. С. 151-204.

Вступ. статья. С. 151-162.

«Любезный дядюшка» (документы о службе Павла Петровича Косяровского) / Вступ. статья и публ. И.А. Зайцевой. С. 205-228.

Вступ. статья. С. 205-213.

Из истории подготовки Собраний сочинений Гоголя:

Об участии Ф.В. Чижова в подготовке «Полного собрания сочинений Н.В. Гоголя» 1862 г. (первое издание наследников) / Вступ. статья и публ. А.С. Шолоховой.

Вступ. статья. С. 229-234.

Письмо Е.В. Быковой к Ф.В. Чижову (16 сентября 1861 г.). С. 234-235.

Письмо Ф.В. Чижова к С.А. Иванову (18 сентября 1861 г.). С. 235-237.

Доверенность Ф.В. Чижову от наследников Н.В. Гоголя для получения его рукописей от С.А. Иванова (28 сентября 1861 г.). С. 237-238.

Доверенность Ф.В. Чижову и И.С. Аксакову от наследников Н.В. Гоголя на издание его сочинений (29 сентября 1861 г.). С. 238-239.

Письмо В.И. Быкова к Ф.В. Чижову (20 октября 1861 г.). С. 240.

Письма А.В. Гоголь-Яновской к Ф.В. Чижову (1861-1862 гг.). С. 240-247.

К истории подготовки 10-го издания «Сочинений Н.В. Гоголя» под редакцией Н.С. Тихонравова и В.И. Шенрока / Вступ. статья и публ. Е.Г. Падериной.

Вступ. статья. С. 248-269.

I. Договор между наследниками и В.В. Думновым о продаже литературных прав на сочинения Гоголя (1886). С. 270-271.

II. Договор между В.В. Думновым и Н.С. Тихонравовым о редакторской подготовке 5 томов «Сочинений Н.В. Гоголя». С. 271-273.

III. Письма В.В. Думнова к Н.С. Тихонравову (1886-1892). С. 274-288.

IV. Письма А.Ф. Бычкова к Н.С. Тихонравову (1886-1893). С. 288-294. 
V. Договор между В.В. Думновым и А.Ф. Марксом о продаже литературных прав на издание сочинений и писем Н.В. Гоголя (1893). С. 294-297.

VI. Соглашение Н.С. Тихонравова на передачу заключенного с В.В. Думновым контракта А.Ф. Марксу (1893). С. 297.

VII. Письма А.Ф. Маркса к Н.С. Тихонравову (1893). С. 297-327.

VIII. Письмо Н.С. Тихонравова к А.Ф. Марксу. Черновые редакции (1893). С. 327-330.

IX. Договоры между А.Ф. Марксом и опекунами наследства Н.С. Тихонравова С.О. Долговым и Е.И. Соколовым (1895). С. 330-333.

Х. Договор между В.И. Шенроком и Н.Н. Печковской (по доверенности А.Ф. Маркса) (1895).

C. 333-335.

ХІ. Письма В.И. Шенрока к А.Ф. Марксу (1895-1896). С. 335-344.

Биография гоголевских автографов и рукописей в документах:

К истории поступления в Румянцевский музей рукописи второго тома «Мертвых душ». По материалам Архива РГБ / Вступ. статья и публ. Е.Г. Падериной.

Вступ. статья. С. 345-354.

Письмо М.Н. Похвиснева к В.А. Дашкову (29 января 1874 г.). С. 354-356.

Письмо В.А. Дашкова к М.Н. Похвисневу (7 февраля 1874 г.). С. 356.

Расписка хранителя отделения рукописей $<$ А.Е.> Викторова в получении собственноручной рукописи Гоголя. С. 356.

Сюжет «Мертвых душ» Гоголя в русской литературе (коррекция, продолжение):

Пономарева А.А. «...Изволь, гениальный человек, я выхожу на вызов твой!»: коллизия исправления читателями «Мертвых душ» (повесть Е.И. Вельтман «Виктор»). С. 359-368.

Дмитриева Е.Е., Шолохова А.С. Мистификация Н.Ф. Ястржембского: « Новые отрывки и варианты» второго тома «Мертвых душ». С. 369-377.

$<$ Ястржембский Н.Ф.> Похождения Чичикова, или Мертвые души. Поэма Н.В. Гоголя. Новые отрывки и варианты / Подгот. текста А.С. Шохоловой. С. 378-403.

[Рец.: Самородницкая Е.И. «Гоголевская мозаика» // Вестник славянских культур. М., 2020. T. 55. C. 308-313.

DOI: $10.37816 / 2073-9567-2020-55-308-313]$

$<$ Гоголь Н.В.> Н.В. Гоголь о христианской жизни / Сост. и вступ. статья И.Р. Монаховой. М.: Книгоизд-во «АБВ», 2019. 208 с.: ил.

Загл. вступ. статьи: «Призвать Христа к себе в домы». С. 7-28.

Мысли Н.В. Гоголя о христианской жизни. Из произведений и писем.

О любви к Богу. С. 20-28.

О любви к ближнему. С. 29-42.

О воплощении христианских заповедей в жизнь. С. 43-46.

О пути к Богу. С. 47-58.

О том, как жить по-христиански. С. 59-70.

О подвиге во имя Бога. С. 71-80.

О любви Бога к человеку. С. 81-88.

О молитве. С. 89-95.

О вере. С. 96-99.

О смирении. С. 100-102.

О самовоспитании. С. 103-116.

О смерти. С. 117-120.

О светлости душевной. С. 121-125.

О воспитании. С. 126-128.

О будущем. С. 129-131.

О труде. С. 132-136.

О препятствиях. С. 137-141.

О несчастьях. С. 142-153.

О счастье. С. 154-156.

О лени. С. 157-158.

О болезнях. С. 159-163.

Об унынии. С. 164-172. 
О благотворительности. С. 173-176.

Молитвы, написанные Н.В. Гоголем. С. 177-180.

Гоголь Н.В. Жизнь. С. 181-185.

Гоголь Н.В. Светлое Воскресенье. С. 186-202.

Адресаты писем Н.В. Гоголя. С. 203-206.

Голубева Е.И. Н.В. Гоголь и Библия: К истокам загадочных смыслов в произведениях писателя. М.: Паломник, 2019. 168 с.

Гольденберг A.X. Творчество Гоголя в мифологическом и литературном контексте: учебное пособие / Волгоградский гос. социально-педагогический ун-т. Волгоград: Научное изд-во ВГСПУ «Перемена», 2019. 108 с.

[Рец.: Иваниикий А.И. // Культура и текст / Алтайский гос. педагогический ун-т. Барнаул, 2020. № 2(41). С. 145-148.]

Гришина Т.Г. [Реферат] // Социальные и гуманитарные науки в России. Сер. 7. Литературоведение. Реферативный журнал ИНИОН РАН. М., 2019. № 1. С. 186-189.]

[Реф. кн.: Русская классика: pro et contra: Железный век: антология / Русская христианская гуманитарная академия; сост., вступ. статьи и коммент. И.А. Есаулова, Т.Г. Петровой; отв. ред. Д.К. Богатырев. СПб.: РХГА, 2018. 1086 с. - (Русский Путь: pro et contra) (Русская классическая литература в мировом контексте).]

Грищзенко Н.A., Ершова Е.О., Старшева М.А. Из истории знакомства англоязычной аудитории с поэмой Н.В. Гоголя «Мертвые души» // Филология и человек / Алтайский гос. ун-т и др. Барнаул, 2019. № 4. С. 83-96.

Грудинина E.B. Чичиков и чичиковщина: проблема духовной деградации личности в русской литературе 19 века // Богословский сборник Тамбовской Духовной семинарии. Вып. 8. Тамбов, 2019. С. 215-223.

Гудин Д.С. Литературные истоки образа утопленницы в романах Е.Г. Водолазкина // Экология языка и речи: Материалы VIII международной научной конференции (Тамбов, 21-23 ноября 2019 г.) / Тамбовский гос. ун-т им. Г.Р. Державина; отв. за выпуск Т.В. Махрачёва. Тамбов 2019. С. 259-262.

[Гоголевская традиция в романном триптихе «Лавр» - «Авиатор» - «Брисбен» Е.Г. Водолазкина.]

Гуминский В.M. Гоголь и русская интеллигенция (к постановке проблемы) // Вестник славянских культур. М., 2019. Т. 53. С. 124-134.

Данте Алигьери: pro et contra: антология: Личность и наследие Данте в оценке русских мыслителей, писателей, исследователей: в 2 т. Т. 2 / Русская христианская гуманитарная академия; сост., вступ. статья М.С. Самариной и И.Ю. Шауба, коммент. М.С. Самариной, И.Ю. Шауба, Е.А. Булучевской. СПб.: РХГА, 2019. 888 с. - (Русский Путь).

Из содерж.:

Гольденберг А.Х. «Гоголь и Данте» как современная научная проблема. С. 547-559.

[Указ. имен.]

Денисов В.Д. «История Иванов» в раннем творчестве Н.В. Гоголя // Культура и текст / Алтайский гос. педагогический ун-т. Барнаул, 2019. № 2(37). С. 168-177.

Джафарова К.К Гоголь о жанре повести // Проблемы гуманитарных наук и образования в современном мире: сб. материалов всероссийской научно-практической конференции (Махачкала, 6 апреля 2019 г.). Махачкала: АЛЕФ, 2019. С. 97-101.

Джафарова К.К. Жанровый полифонизм в «Арабесках» Гоголя // Проблемы гуманитарного образования в аспекте новых научных парадигм: сб. материалов всероссийской научно-практической конференции (Махачкала, 18 декабря 2019 г.). Махачкала: АЛЕФ, 2019. С. 75-77. 
Джафарова К.К. К вопросу о жанровом своеобразии «Выбранных мест из переписки с друзьями Н.В. Гоголя» // Вестник Дагестанского гос. ун-та. Серия 2. Гуманитарные науки. Махачкала, 2019. Т. 34. Вып. 3. С. 31-37.

DOI: $10.21779 / 2542-0313-2019-34-3-31-37$

Джурова Т.С. Ревизия «Ревизоров» // Петербургский театральный журнал. СПб., 2019. № 1(95). С. 60-65.

[«Ревизор» Гоголя А. Сидельникова в Санкт-Петербургском театре «Суббота», О. Липовецкого в Ульяновском драматическом театре им. И.А. Гончарова, П. Шерешевского в Псковском театре драмы им. А.С. Пушкина.]

Дударева А.А., Ерохин В.Н. Истинное православие: протопоп Аввакум и Н.В. Гоголь. типологические параллели // Тенденции развития современной отечественной филологии: Материалы научно-практической конференции, приуроченной к 65-летию профессора филологического факультета ТвГУ В.В. Волкова (Тверь, 17 октября 2019 г.) / Тверской гос. ун-т. Филологический факультет; сост. И.В. Гладилиной. Тверь, 2019. С. 136-143.

Дударева М.А., Аталян Г.Б. Трансформация фольклорной традиции в прозе Н.В. Гоголя («Ночь перед Рождеством») и Э.Т.А. Гофмана («Приключение в ночь под новый год») // Филологические науки. Вопросы теории и практики. Тамбов: Грамота, 2019. T. 12. № 5. C. 101-104.

DOI: 0.30853/filnauki.2019.5.22

Духовное слово русских поэтов. Стихи, вознесшиеся к небу / Сост., вступ. статья, биогр. статьи В.И. Калугина. М.: Вече, 2019. 544 с.: ил. 1300 экз.

Загл. вступ. статьи: Молитвенная поэзия. С. 5-24.

[О Гоголе: С. 13-15, 17-19, 21.]

Из содерж.:

Николай Гоголь.

Биогр. статья. С. 243.

Молитвы

На $1846<$ год> («Господи, благослови на сей грядущий год...»). С. 243.

«Влеки меня к Себе, Боже мой...». С. 243-244.

«Господи, дай мне помнить вечно мое...». С. 244.

«Боже, соделай безопасным путь его...». С. 244.

«Господи! спаси и помилуй бедных людей...». С. 244.

«Милосердия Господи, Ты милосерд!..». С. 245.

«Боже, дай полюбить еще больше людей...». С. 245.

«Молюсь о друзьях моих...». С. 245.

«К Тебе, о Матерь Пресвятая!..». С. 245.

Воропаев B. Коммент. С. 245-246.

Размышления о Божественной Литургии. С. 246.

[То же: // Молитвы русских поэтов XI-XIX: Антология / Авторский проект, сост., послесл. и биогр. статьи В.И. Калугина. 2-е изд., испр. и доп. М.: Вече, 2012. 912 с.]

Елистратов В.С. Из словаря рассказов Н.В. Гоголя: «Коляска» // Русский язык в школе и дома. М., 2019. Т. 19. № 3. С. 3-5.

Елистратов В.С. Из словаря рассказов Н.В. Гоголя: «Невский проспект» // Русский язык в школе и дома. М., 2019. Т. 19. № 4. С. 3-7.

Елистратов В.С. Из словаря рассказов Н.В. Гоголя: «Нос» // Русский язык в школе и дома. М., 2019. Т. 19. № 5. С. 3-8.

Елистратов В.С. Из словаря рассказов Н.В. Гоголя: «Портрет» // Русский язык в школе и дома. М., 2019. Т. 19. № 6. С. 3-5.

Елистратов В.С. Словарь языка Н.В. Гоголя: «Шинель» // Русский язык в школе и дома. М., 2019. Т. 19. № 2. С. 3-8. 
Ельницкая Л. М. Мифы русской литературы: Гоголь, Достоевский, Островский, Чехов. 2-е изд., стереотип. М.: URSS, 2019. 208 с.

Н.В. Гоголь. С. 10-57.

Еремеева А.С. Традиции сатиры в русской литературе. ХІ класс // Уроки литературы. Приложение к журналу «Литература в школе». М., 2019. № 1. С. 11-14.

[В частности, о «Ревизоре» Гоголя.]

Ермоленко Г.Н. [Рецензия] // Вопросы литературы. М., 2019. № 3. С. 296-299.

[Рец. на кн. Манн Ю.В. Карпо Соленик: «Решительно комический талант». М.: Новое литературное обозрение, 2018. 184 с.]

Ерофеев В. Небесные гости Гоголя // Огонек. М., 2019. № 10. С. 34-35.

[К 210-летию со дня рождения Гоголя.]

Ершов А.Г. «Ночи на вилле» как претекст «Выбранных мест из переписки с друзьями» // Вестник Санкт-Петербургского гос. ун-та технологии и дизайна. Серия 2. Искусствоведение. Филологические науки. СПб., 2019. № 1. С. 102-107.

Жиленкова И.И., Титова А.С. Прецедентное имя «Плюшкин» в коммуникативном сознании современного поколения // Филологические науки. Вопросы теории и практики. Т. 13. №3. Тамбов: Грамота, 2020. С. 107-110.

DOI: 10.30853/filnauki.2020.3.22

Житкова Л.Н. Школьный курс русской классической литературы (программа 9-го класса) и религиозный дискурс // Церковь. Богословие. История: Материалы VII всероссийской научно-богословской конференции, посвященной 100-летию мученической кончины святых Царственных страстотерпцев и их верных спутников (Екатеринбург, 8-10 февраля 2019 г.) / Екатеринбургская Духовная семинария; ред. А.А. Зайцев, П.И. Мангилёв и др. Екатеринбург, 2019. С. 223-229.

[В частности, Д.С. Мережковский о Гоголе.]

Завгородний А. «Мертвые души» Э. Шаррьера // Новое литературное обозрение. М., 2019. № 1(155). С. 198-210.

[Эрнест Шаррьер как автор первого полного французского перевода поэмы Гоголя «Мертвые души» (1859).]

Зырянова О.Н., Бахор Т.А., Мазурова Н.А. Рецепция Н.В. Гоголя в драматургии Н. Садур // Человек и язык в коммуникативном пространстве: сб. научных статей / Сибирский федеральный ун-т. Красноярск 2019. № 10. С. 108-115.

[Особенности рецепции повести Гоголя «Вий» в пьесе Н. Садур «Панночка».]

Иванова Я.Н., Степанчиков М.А. Историзмы в поэме Н.В. Гоголя «Мертвые души». IX класс // Литература в школе. М., 2019. №5. С. 33-35.

Иванова-Лукьянова Г.Н. Ритм прозы от Карамзина до Чехова: монография. 2-е изд., стер. М.: ФЛИНТА, 2019. 336 с.

Н.В. Гоголь. С. 93-128.

Природа и ритм в творчестве Н.В. Гоголя.

Ритм и смысл: Миргород», «Петербургские повести».

Портретные описания: Миргород», «Петербургские повести».

Ритмические портреты героев «Мертвых душ».

Ритм лирических отступлений в «Мертвых душах».

[1-е изд.: М., 2017.]

Ивинский Д.П. Пушкин и его время. М.: Р. Валент, 2019. 320 с.

Из содерж.:

Гоголь и Пушкин: к постановке вопроса. С. 286-293.

[Впервые: Научные доклады филологического факультета МГУ. Т. 6. М., 2010. С. 78-84.]

Гоголь, Пушкин, Мицкевич и летящие по воздуху кони. С. 294-304.

[Впервые: Бестиарий движений: сб. статей. Тула, 2018. С. 48-55.] 
Ильичёва Н.И. Лайт-опера - новый жанр музыкального театра XXI [века] // Музыка и время. М., 2019. №4. С. 25-28.

[Анализ лайт-оперы А. Пантыкина «Гоголь. Чичиков. Души» (композитор и сценарист К. Рубинский) по мотивам поэмы «Мертвые души», комедии «Игроки» и других произведений Гоголя.]

Калганова Т.А. О книге Ю.В. Манна «Карпо Соленик - решительно комический талант» // Литература в школе». М., 2019. №6. С. 21.

[Рец. на кн. Манн Ю.В. Карпо Соленик: «Решительно комический талант». М.: Новое литературное обозрение, 2018. 184 с.]

[Из аннотации: «Решительно комический талант!» Эта формула принадлежит Гоголю, который охарактеризовал таким образом особенности дарования выдающегося провинциального актера Карпо Соленика (1811-1851). Гоголь предполагал, что Соленик будет исполнять роль Хлестакова на премьере спектакля «Ревизор» в Александринском театре. Если бы это случилось, мы, возможно, знали бы о нем гораздо больше, чем сейчас. Его талант высоко ценили современники - Плетнев, Данилевский, Щепкин, Шевченко. Об актере писали: «Выполняя роли из произведений Грибоедова, Гоголя, Мольера, - Соленик, касательно заслуг своих в этом случае, стоял, быть может, наравне с этими писателями...»]

Карташов В.С. Выписки Н.В. Гоголя из «народных праздников и обычаев» книги И.П. Сахарова «Сказания русского народа» // Актуальные проблемы современной науки. М., 2019. № 3(106). С. 55-56.

Карташов В.С. Н.В. Гоголь в исповедных ведомостях церкви Саввы Освященного в Москве // Актуальные проблемы современной науки. М., 2019. № 3(106). С. 57-58.

Кондратьев А.С., Анисимов П.Д. Поэма Н.В. Гоголя «Мертвые души»: духовный опыт героя в контексте «большого времени» // Филоlogos / Елецкий нос. ун-т им. И.А. Бунина. Елец, 2019. № 3(42). С. 45-51.

DOI: $10.24888 / 2079-2638-2019-42-3-45-51$

Концевич И.М. Оптина Пустынь и ее время / Перепечатка с изд. Свято-Троицкого монастыря в Джорданвилле (США), 1979, перераб. и доп. Введенский ставропигиальный мужской монастырь Оптина Пустынь, 2019. 681 с.: ил.

Гл. XIX: Оптина Пустынь и писатели, ее посещавшие.

Николай Васильевич Гоголь. С. 612-615.

[Указ. имен.]

Кормилов С.И. Социально-историческое своеобразие комизма в гоголевском «Ревизоре» (статья первая) // Новый филологический вестник. М., 2019. №3(50). С. 53-61.

Краснокутская С.Д. Пространственная оппозиция «свое-чужое» в цикле повестей Н.В. Гоголя «Вечера на хуторе близ Диканьки» // Научный форум: филология, искусствоведение и культурология: сб. статей по материалам XXIV международной научно-практической конференции (Москва, 11 апреля 2019 г.). Т. 3(24) / Редкол.: Т.А. Воробьева, Н.А. Лебедева (председатель) и др. М., 2019. С. 64-68.

Краснокутская С.Д. Языковые средства выражения мифологического пространства в повести Н.В. Гоголя «Страшная месть» // Современный ученый. Белгород, 2019. № 4. C. $236-239$.

Красовский B.E., Леденев A.B. Русская литература: учебник для академического бакалавриата / Под общ. ред. В.Е. Красовского. М.: Изд-во Юрайт, 2019. 650 с. - (Серия Бакалавр. Академический курс).

Красовский В.Е. Николай Васильевич Гоголь (1809-1852). С. 163-211.

Кривонос В.Ш. «Мертвые души» Гоголя: Пространство смысла: монография. Изд. 4-е. М.: ФЛИНТА,2019. 320 с. 
Крижановский Н.И., Онищенко Е.В. Восприятие В.В. Розановым и М.О. Меньшиковым личности и творчества Н.В. Гоголя // Филологические науки. Вопросы теории и практики. Тамбов: Грамота, 2019. Т. 12. № 3. С. 382-388.

DOI: 10.30853 /filnauki.2019.3.80

Кудина А.Ю. «Текст-продолжение» «Мертвые души, том 2» Ю.А. Авакяна: стилизация по сохранившимся фрагментам оригинального текста // Вестник Тверского гос. ун-та. Серия Филология. Тверь, 2019. №3(62). С. 223-228.

[Оригинальный текст, сохранившиеся фрагменты второго тома поэмы «Мертвые души» Гоголя, и вторичный текст, поэма «Мертвые души, том 2» Ю.А. Авакяна, исследуются с позиций теории интертекстуальности, предложенной Ж. Женеттом, и теории «вторичных текстов» М.В. Вербицкой.]

Кудина А.Ю. Языковая стилизация как художественный прием в «тексте-продолжении» «Мертвые души. Том 2» Ю.А. Авакяна // Вестник Тверского гос. ун-та. Серия Филология. Тверь, 2019. №4(63). С. 238-242.

Кулабухова М.А., Кулабухова В.А., Кулабухов Д.А. Н.В. Гоголь: избранные аспекты феноменальности личности и творческого наследия (к 210-летию со дня рождения писателя) // VIII Сильвестровские педагогические чтения. Духовность и нравственность в образовательном пространстве: осмысление свободы и ответственности молодежи: Материалы всероссийской научной конференции (Тара, 5 апреля 2019 г.) / Отв. ред. О.Р. Каюмов. СПб.: Амфора, 2019. С. 130-139.

Лавриеня E. Творчество и личность Н.В. Гоголя в современной киноинтерпретации (на материале киносериала С. Баранова «Гоголь») // Актуальная классика: Материалы Третьих студенческих научных чтений (Москва, 18 апреля 2019 г.). М.: Литера, 2019. С. 121-128.

Лазарева В.И., Юрьева Е.В. Мистицизм в творчестве Н.В. Гоголя // Научно-технические достижения студентов, аспирантов, молодых ученых строительно-архитектурной отрасли: сб. научных трудов V республиканской конференции молодых ученых, аспирантов, студентов. (Макеевка, 19 апреля 2019 г.). Т. 3: Гуманитарные науки / Донбасская национальная академия строительства и архитектуры. Макеевка, 2019. С. 129-134.

Лазарева В.И., Юрьева Е.В. Мистические мотивы в произведениях Н.В. Гоголя // Актуальные проблемы речевой культуры будущего специалиста: Материалы I республиканской студенческой научно-практической конференции, посвященной Году русского языка в Донецкой Народной Республике (Донецк, 22 мая 2019 г) / Донецкий национальный технический ун-т; редкол.: И.А. Мачай, Л.К. Лазарева, Е.В. Юрьева. Донецк, 2019. С. 145-149.

$<$ Лазарь (Афанасьев)> Монах Лазарь (Афанасьев). Здесь начинается Рай: сб. духовной поэзии / Ред.-сост. Н.Е. Афанасьева; предисл. В.А. Воропаева; рис. В.В. Полякова. М.: Русскій Хронографъ, 2019. 528 с.: ил.

Из содерж.:

Гоголь. С. 408-409.

Леонтьева А.Ю., Филимоненко Р.А. Интертекстуальный аспект литературного типа «маленький человек» в прозе Г.И. Газданова // Лучшая научная статья 2019: сб. статей XXIV международного научно-исследовательского конкурса (Пенза, 30 апреля 2019 г.) / Отв. ред. Г.Ю. Гуляев. Пенза, 2019. С. 114-118.

[Традиции А.С. Пушкина и Гоголя в интерпретации Г.И. Газданова.]

Ли Аньии. История изучения повести «Записки сумасшедшего» Лу Синя в Китае в контексте влияния одноименного произведения Н.В. Гоголя // Litera. M., 2019. №4. С. 26-34. DOI: $10.25136 / 2409-8698.2019 .4 .30419$

Ли Аньции. Лу Синь как переводчик поэмы Н.В. Гоголя «Мертвые души» // Казанская наука. Казань, 2019. № 9. С. 11-15.

[История перевода поэмы Гоголя «Мертвые души» китайским писателем Лу Синем.] 
Линков В.Я. Введение в литературоведение: История идей от Вико до Бахтина и Гадамера. М.: ЛЕНАНД, 2019. 132 с.

[Указ. имен.]

Литература в школе: научно-методический журнал. М., 2019. № 3.

\section{Содерж.:}

Наши духовные ценности. К 200-летию со дня рождения Н.В. Гоголя

Лебедев Ю.В. О реализме Гоголя. С. 2-7.

[Духовные корни реализма Гоголя. Соотношение творчества и эстетических позиций Гоголя и А.С. Пушкина. Тема духовного спасения русских людей в поэме «Мертвые души».]

Виноградская Н.Л., Зайщева И.А. «...Как идет дело и печатанье»: О полном собрании сочинений и писем Н.В. Гоголя в 23 томах. С. 8-10.

[О работе Института мировой литературы им. А.М. Горького РАН над изданием академического Полного собрания сочинений Н.В. Гоголя. Основные текстологические проблемы, цели академического комментирования.]

Монахова И.Р. «Открылась внутренняя гармония»: полемика В.Г. Белинского и К.С. Аксакова о «Мертвых душах». С. 11-13.

Манн Ю.В. Повесть Н.В. Гоголя «Нос»: снятие носителя фантастики. Гоголь и Кафка. С. 14-19. Немиев H. Тема безумия в «Записках сумасшедшего» Н.В. Гоголя и в повести С.Д. Кржижановского «Автобиография трупа». С. 20-22.

Роговер Е.С. Повесть Гоголя «Записки сумасшедшего». С. 22-26.

[Тема безумия в литературе. Связь повести Гоголя с романтической литературой и темой «маленького человека».]

Сазонова Л.И. Средневековая новелла о художнике и повесть Гоголя «Портрет». С. 26-32.

[Иконографические сюжеты Средневековья и изображение художников в повести Гоголя.]

Чертов В.Ф. Творчество Н.В. Гоголя в школьном изучении: сравнительно-исторический аспект. C. 33-35.

[Из истории школьного освоения творческого наследия Гоголя в дореволюционный, советский и современный периоды. Сопоставление задач изучения, критериев отбора произведений, подходов к их анализу, основные методические проблемы.]

Калганова Т.А. Изучение повести Н.В. Гоголя «Ночь перед Рождеством»: материалы к уроку. VI класс. С. 36-38.

[В частности, влияние житийной литературы на сюжет повести.]

Belousova E.И. Комментарии при изучении комедии Н.В. Гоголя «Ревизор». С. 39-43.

[Понятие «комментарий», возможности использования комментариев на разных этапах чтения и анализа комедии школьниками].

Литература и философия: От романтизма к ХХ веку. К 150-летию со дня смерти В.Ф. Одоевского / Отв. ред. и сост. Е.А. Тахо-Годи. М.: Водолей, 2019. 660 с. - (Серия Русская литература и философия: пути взаимодействия. Вып. 3).

Из содерж.:

Bоропаев В.A. Н.В. Гоголь и князь В.Ф. Одоевский: Программные статьи в пушкинском «Современнике». С. 52-57.

Виноградов И.А. Князь В.Ф. Одоевский, Н.В. Гоголь и «Журнал Министерства Внутренних Дел»: К постановке проблемы. С. 58-70.

Гуминский В.М. К проблеме самобытного развития русской литературы: Гоголь и другие. С. 71-80.

Люстров А.М. Повесть Н.В. Гоголя «Тарас Бульба». Судьба двух редакций в школьном каноне // Летняя школа по русской литературе / Петербургский институт иудаики. СПб., 2019. T. 15. №2-3. C. 160-173.

DOI: $10.26172 / 2587-8190-2019-15-2-3-160-173$

Макарова Е.П. Повесть Н.В. Гоголя «Шинель»: титулярный советник Башмачкин. VIII класс // Литература в школе: научно-методический журнал. М., 2019. № 10. С. 18-20.

Макшеева Н.В. Смысловая функция упоминания имени «святого» в «Ревизоре» Н.В. Гоголя // VIII Сильвестровские педагогические чтения. Духовность и нравственность в образовательном пространстве: осмысление свободы и ответственности молодежи: Ма- 
териалы всероссийской научной конференции (Тара, 5 апреля 2019 г.) / Отв. ред. О.Р. Каюмов. СПб.: Амфора, 2019. С. 144-147.

[Художественная функция детали комедии Гоголя «Ревизор»: упоминания имени «святого Василия Египтянина» в связи с приездом Хлестакова. Обосновывается мифический характер этого «святого».]

Манн Ю.В. «Гоголю я посвятил больше всего времени...» // Литература в школе. М., 2019. № 6. C. 20.

Манн Ю.В. Н.В. Гоголь: тайны биографии и тайны творчества. М.: РГГУ [Российский гос. гуманитарный ун-т], 2019. 143 с.

Парадокс о Гоголе (Вместо предисловия)

Путешествие «Носа» продолжается...

«Женитьба» Гоголя: третье измерение

Гоголь и Кьеркегор: «таинственная невстреча»

Гоголь открывает Город

«Портрет» Гоголя: есть ли у литературы граница?

Повесть Гоголя «Рим», или Преодоление канона

Тайна «гомеровского вопроса»

«Мертвые души»- утопия?

«Мертвые души» - наша «Божественная комедия»?

Всемирная отзывчивость Гоголя

Что случилось со вторым томом «Мертвых душ»?

«Прощальная повесть»- прощание?

«Вся жизнь моя в письмах...» (Вместо послесловия)

Мащенко А.П. Крымское измерение русской литературы: от Пушкина до Прилепина // Ученые записки Крымского федерального ун-та им. В.И. Вернадского. Филологические науки. Симферополь, 2019. Т. 5(71). № 1. С. 70-92.

[C. 74: «В июне 1835 года в Крым, в Саки, приезжает на лечение Николай Гоголь. О лечебных свойствах сакских грязей автор «Тараса Бульбы» узнал из сочинений другого российского литератора Павла Сумарокова: «Путешествие по Крыму и Бессарабии» и «Досуги крымского судьи, или Второе путешествие в Тавриду». Причем, судя по всему, сакские грязи Гоголю помогли, иначе едва ли он задумывал бы снова ехать в Крым лечиться уже в конце жизни. Увы, в силу разных причин, прежде всего - безденежья, эта поездка так и не состоялась».]

Междисциплинарные связи при изучении литературы: сб. научных трудов. Вып. 8 / Саратовский национальный исследовательский гос. ун-т им. Н.Г. Чернышевского; под ред. Т.Д. Беловой, А.Л. Фокеева; отв. секретарь М.А. Шеленок. Саратов, 2019. С. 168-171.

[Материалы VIII всероссийской научно-практической конференции, посвященной 110-летию Саратовского гос. ун-та (Саратов, 30-31 мая 2019 г.).]

Из содерж.:

Князева Е.П. Неизвестный факт творческой истории романа О.Д. Форш «Ворон». С. 78-87.

[Творческая история романа О.Д. Форш «Ворон»; публикуется не вошедшая в окончательный вариант и хранящаяся в архиве писательницы фантастическая глава, в которой описывается эксгумация тела Гоголя.]

Рясов Д.Л. Образы немцев в творчестве А.П. Чехова: продолжение гоголевской традиции. C. $168-171$.

[Персонажи-немцы в произведениях Гоголя и А.П. Чехова; параллели между текстами писателей, связанные с немецкой темой.]

Международная научная конференция «Духовное и культурное наследие монастырей Русской Православной Церкви. К 500-летию Московского Новодевичьего монастыря» (Москва, 9-11 октября 2011 г.): Тезисы докладов / ИМЛИ РАН; отв. ред. М.И. Щербакова. М.: ИМЛИ РАН 2019. 208 с.

Из содерж.:

Виноградов И.А. Н.В. Гоголь и русские монастыри. С. 31-33.

Воропаев В.A. Могила Гоголя в Новодевичьем монастыре. С. 43-45.

Захарченко С.О. Эпистолярное наследие преподобного Макария Оптинского. С. 65-69. 
[В частности, восстановление купюры в тексте письма старца Макария к его духовной дочери А.И. Воейковой от 26 января 1849 г. позволило уточнить время пребывания Гоголя на Корфу.] Шульи С.А. Образ монастыря в творчестве Н.В. Гоголя и статья П.А. Флоренского «Троице-Сергиева лавра и Россия». С. 193-196.

Мельникова Г.Т. «Свежий ветер и черные мысли» Петербурга (по повести Н.Ф. Павлова «Демон») // Вестник Томского гос. педагогического ун-та. Томск, 2020. № 3(209). С. 7-13. [В частности, Н.Ф. Павлов как предшественник Гоголя в раскрытии темы «маленького человека» в русской литературе.]

Миллионщикова T.M. Мотив сна в произведениях русских писателей XIX в. в работах литературоведов США (обзор) // Социальные и гуманитарные науки. Отечественная и зарубежная литература. Серия 7. Литературоведение. Реферативный журнал / Институт научной информации по общественным наукам РАН. М., 2019. № 1. С. 48-51.

[В частности, на материале произведений Гоголя.]

Мокляк В.И. Циклизация в творчестве русских романтиков // Верхневолжский филологический вестник / Ярославский гос. педагогический ун-т им. К.Д. Ушинского. Ярославль, 2019. № 2(17). С. 25-29.

[На материале творчества Гоголя и О.М. Сомова.]

Монахова И.Р. Памятники Н.В. Гоголю в Москве // Литература в школе. М., 2019. № 5. С. 7-9. [Памятники Гоголю в Москве (на Никитском бульваре, Гоголевском бульваре, Новодевичьем кладбище).]

Мосунова Л.А. Православная книга в аспекте ее влияния на русскую литературу // Вестник гуманитарного образования / Вятский гос. ун-т. Киров, 2019. № 1(13). С. 101-109. DOI: $10.25730 /$ VSU.2070.19.011

[В частности, Гоголь как церковный писатель.]

Муллина Д.А. Трансформация классического сюжета в пьесе Н. Садур «Брат Чичиков» // Мир науки, культуры, образования. Горно-Алтайск, 2019. № 2(75). С. 369-372.

«Не будьте мертвыми душами»: К 210-летию со дня рождения Н.В. Гоголя: Каталог выставки (31 марта - 30 апреля 2019 г.) / Сост. Н.В. Бородулина. Ростов-на-Дону, 2019. 19 с.

Некрасова A.B. Лексемы грех и добродетель в духовной прозе Н.В. Гоголя: узуальные и контекстуальные значения и смыслы // Тенденции развития современной отечественной филологии: Материалы научно-практической конференции, приуроченной к 65-летию профессора филологического факультета ТвГУ В.В. Волкова (Тверь, 17 октября 2019 г.) / Тверской гос. ун-т. Филологический факультет; сост. И.В. Гладилиной. Тверь, 2019. С. 155-163.

[Узуальные и контекстуальные значения и смыслы лексем грех и добродетель в «Выбранных местах из переписки с друзьями» и «Размышлениях о Божественной Литургии» Гоголя.]

Некрасова А.В., Аксенова А.T. Семантико-стилистическое своеобразие лексем с дескрипторными компонентами грех- / греш- и добродетел'- в «Выбранных местах из переписки с друзьями» Н.В. Гоголя // Воспитание языкового вкуса студентов в процессе преподавания русской словесности: Материалы докладов и сообщений XXIV международной научно-методической конференции (Санкт-Петербург, 8 февраля 2019 г.) / Санкт-Петербургский гос. ун-т промышленных технологий и дизайна; ред. Т.А. Налимова, Н.Ю. Романова, М.А. Шахматова; отв. ред. Н.Т. Свидинская. СПб., 2019. С. 54-58.

Новикова-Строганова А. Высокое назначение человека // Литературная газета. М., 2019. 1 апреля.

[К 210-летию со дня рождения Гоголя.]

Новикова-Строганова А. Высокое назначение человека. К 210-летию Н.В. Гоголя // Дальний Восток. Хабаровск, 2019. № 4. 
Носкова В.А. Комические парные персонажи в творчестве Н.В. Гоголя // Русский язык и литература: актуальные проблемы теории и практики преподавания: сб. материалов IV всероссийской научно-методической конференции (Коломна, 26 марта 2019 г.) / Гос. социально-гуманитарный ун-т; под ред. М.А. Дубовой, Т.А. Капыриной. Коломна, 2019. C. 235-242.

Осипова E.A. К вопросу о русско-сербских литературных пересечениях // Два века русской классики: научный филологический журнал / ИМЛИ имени А.М. Горького РАН. M., 2019. № 1. C. 148-157.

DOI 10.22455/2686-7494-2019-1-1-148-157

[Рец. на кн.: Классики и современность: Гоголь, Тургенев, Горький / Сост. А. Вранеш, Л. Маркович, А. Шешкен. Белград: Филологический факультет Белградского ун-та; М.: Московский гос. ун-т им. М.В. Ломоносова; Тюмень: Тюменский гос. ун-т; Воронеж: Воронежский гос. ун-т, 315 с. - (Библиотека Язык и литература. Сер. Труды о языке и литературе; кн. 19).]

Осиповский О.Е. [Рецензия] // Вопросы литературы. М., 2019. № 1. С. 276-279.

[Рец. на кн.: Шульи C.A. Поэма Гоголя «Мертвые души»: внутренний мир и литературно-философские контексты. СПб.: Алетейя, 2017. 288 с.]

От истории текста к истории литературы / Отв. ред. М.И. Щербакова. Вып. 2. М.: ИМЛИ РАН, 2019. 592 с.

Из содерж.:

Ecuпов B.М. Отдельные проблемы текстологии поэтического творчества А.С. Пушкина. С. 51-83. Виноградов И.А. Единственный автограф повести Н.В. Гоголя «Вий». С. 117-162.

Зайцева И.А. «Тридцать пять тысяч курьеров» (Сцена вранья в гоголевском «Ревизоре»: история создания и публикации). С. 163-190.

Падерина Е.Г. Эксперименты в академической эдиции поврежденных автографов Гоголя: границы допустимого и значение допущенного. С. 191-207.

Дмитриева Е.Е., Шолохова А.С. История изданий второго тома «Мертвых душ»: утраченная и обретенная рукопись. С. 208-260.

Падерина Е.Г. К истории сохранения и изучения черновых рукописей Гоголя (Н.С. Тихонравов и Д.Ф. Самарин) // Вестник славянских культур. М., 2019. Т. 52. С. 158-169.

Падерина Е.Г. «Всё - ум, везде - ум»: Гоголевский мотив в философии Кречинского // Сюжетология и сюжетография / Институт филологии Сибирского отделения РАН. Новосибирск, 2019. № 2. С. 14-23.

DOI: $10.25205 / 2410-7883-2019-2-14-23$

[На материале комедии Гоголя «Игроки» и пьесы А.В. Сухово-Кобылина «Свадьба Кречинского».]

Петербургский текст Гоголя // Культура и текст /Алтайский гос. педагогический ун-т. Барнаул. 2019. № 2(37). С. 224.

[О кн.: Денисов В.Д. Петербургский текст Гоголя. СПб.: Нестор-История, 2018. 384 с.]

Петров В.В. Стратегии интерпретации поэмы Н.В. Гоголя «Мертвые души» в фанфикшн-словесности // Новейшая филология: итоги и перспективы исследований: сб. статей международной научно-практической конференции, посвященной памяти Б.И. Осипова и М.П. Одинцовой (Омск, 15-16 февраля 2019 г.) / Омский гос. ун-т им. Ф.М. Достоевского; отв. ред. О.В. Золтнер. Омск, 2019. С. 336-339.

[Исследование границ вариативности поэмы Гоголя «Мертвые души» в фанфикшн-текстах. Выделены три основные повествовательные стратегии, избранные фикрайтерами для моделирования собственного сюжета по мотивам классического произведения. Во-первых, фикрайтеры пародируют гоголевский сюжет. Во-вторых, читатели-писатели создают лирические тексты по мотивам «Мертвых душ» в духе дидактической поэзии. В-третьих, авторы фанфиков трансформируют авантюрный сюжет о герое-путешественнике или плуте-соглядатае.]

Петрова Е.С. О влиянии «Кандида» Вольтера и «Тристрама Шенди» Лоренса Стерна на «Нос» Н.В. Гоголя и «Село Степанчиково» Ф.М. Достоевского // Летняя школа по русской литературе / Петербургский институт иудаики. СПб., 2019. Т. 15. №4. С. 348-360. DOI: $10.26172 / 2587-8190-2019-15-4-348-360$ 
Плетнева A.А. Пушкин, Гоголь и Бова: аллюзии к лубочной литературе в произведениях русской классики // Русская речь. М., 2019. № 1. С. 74-87.

DOI: $10.31857 / \mathrm{S} 013161170003976-2$

[Лубочные источники повести Гоголя «Нос».]

Пономарева Т.А. Традиции Н.В. Гоголя в прозе С.А. Клычкова // Вестник Российского ун-та дружбы народов. Серия: Литературоведение. Журналистика. М., 2019. Т. 24. № 3. C. 355-365.

DOI: $10.22363 / 2312-9220-2019-24-3-355-365$

Пронина А.Ф. Опера «Нос» Д. Шостаковича и эксперименты В. Мейерхольда // Интеграция искусств в современном художественном образовании: Материалы II всероссийской (с международным участием) научно-практической конференции (Орел, 16 мая 2019 г.) / Орловский гос. ин-т культуры. Орел, 2019. С. 38-40.

Просветитель и романтик: памяти профессора Московского университета А.А. Смирнова (1941-2014) / Сост. и отв. ред. А.В. Лебедев. М.; СПб.: Нестор-История, 2019. 616 с.: ил. Из содерж.:

Михед П.В. Гоголь в канонах украинской и русской культур (замечания к проблеме). С. 193-201. Лебедев А.В. Гоголевские интертексты как один из способов воплощения феномена «кухонного витийства» в поэзии Л.В. Лосева. С. 376-388.

Райкина М. «Городничий - я. Кто же еще?» В. Машков раскрыл планы «Табакерки» // Комсомольская правда. М., 2019. 5 сентября. № 195(28.067). С. 8.

[В ноябре планируется премьера «Ревизора» Гоголя (режиссер С. Газаров).]

Райкина М. К нам влетает «Ревизор». Постановка сразила зрителей наповал своим феерическим прочтением великого классика // Комсомольская правда. М., 2019. 29 ноября. № 266(438). С. 15.

[В театре Олега Табакова «Табакерка» прошла премьера «Ревизора» Гоголя (режиссер С. Газаров).]

Райкина М. Полет «Ревизора» над городом Машкова. Режиссер Сергей Газаров: «Почему мы все время верим идиотам, и они делают нашу жизнь?» // Комсомольская правда. М., 2019. 5 ноября. № 245(28.117). С. 7.

[В театре Олега Табакова «Табакерка» готовится премьера «Ревизора» Гоголя (режиссер С. Газаров).]

Робинов О.Ю. «Genius loci». История создания Государственного бюджетного учреждения культуры города Москвы «Дом Н.В. Гоголя - мемориальный музей и научная библиотека» // Литературные музеи в контексте истории и культуры: всероссийская научная конференция под эгидой Ассоциации литературных музеев Союза музеев России (Москва, 2-3 июня 2018 г.): сб. статей / Гос. музей истории российской литературы им. В.И. Даля; отв. ред. Д.П. Бак. М.: Литературный музей, 2019. С. 91-97.

[«Genius loci»- мемориальное место, отождествляемое с героем, который в нем существовал; на примере истории возникновения первого в России музея Гоголя - «Дома Н.В. Гоголя - мемориального музея и научной библиотеки», ставшего за годы своего существования научным центром изучения жизни и творчества писателя].

Рожкова Е.А. Вакенродеровские образы в персонажной системе повести Н.В. Гоголя «Портрет» // Диалог культур - диалог о мире и во имя мира: Материалы Х международной студенческой научно-практической конференции (Комсомольск-на Амуре, 25 апреля 2019 г.) / Амурский гуманитарно-педагогический ун-т. Комсомольск-на Амуре, 2019. С. 231-235.

[Повесть Гоголя «Портрет» и «Сердечные излияния отшельника - любителя искусств» В.Г. Вакенродера.]

Руцкий С.И., Лазарева Л.К. О фольклорной основе повести Н.В. Гоголя «Страшная месть» // Актуальные проблемы речевой культуры будущего специалиста: Материалы I республиканской студенческой научно-практической конференции, посвященной Году русского языка в Донецкой Народной Республике (Донецк, 22 мая 2019 г) / Донецкий национальный технический ун-т; редкол.: И.А. Мачай, Л.К. Лазарева, Е.В. Юрьева. Донецк, 2019. С. 172-175. 
Савченко А.В., Бодрова А.Г. Украинский язык в русском контексте: образность, фольклор и этносимволика (на примере эпиграфов в повести Н.В. Гоголя «Сорочинская ярмарка») // Этническая культура / Чувашский гос. ин-т культуры и искусства. Чебоксары, 2019. № 1(1). С. 55-58.

Садеги Сахлабад Зейнаб. Тень «Шинели» Н.В. Гоголя над рассказами Дж. Але-Ахмада // Наука и школа / Московский педагогический гос. ун-т. М., 2019. № 6. С. 26-32.

[Гоголевская традиция в рассказах иранского писателя Дж. Але-Ахмада.]

Сараскина Л.И. Лики Гоголя в документальном российском кинематографе // Язык. Культура. Коммуникация / Нижегородский гос. лингвистический ун-т им. Н.А. Добролюбова. Нижний Новгород, 2019. № 22. С. 358-377.

[Анализируются семь документальных фильмов о Гоголе российского производства (20012009 гг.).]

Сартаков E.B. Русская литература. Просто о важном. Стили, направления и течения. M.: Эксмо, 2019. 128 с. - (Level One. Новый уровень знаний).

Из содерж.:

Н.В. Гоголь. «Ревизор»: три загадки великой комедии.

Как Пушкин приложил руку к пьесе. С. 53-54.

Почему Гоголю не понравилась премьера. С. 54-56.

Но зачем же стены ломать? С. 56.

В чем смысл немой сцены. С. 56-59.

Н.В. Гоголь. «Мертвые души»: Недописанная утопия.

Подарок Пушкина. С. 60.

Русское колесо. С. 61.

Лестница Иоанна. С. 62-64.

Череп на обложке. С. 64-67.

Куда несется птица-тройка. С. 67-69.

Cизых О.В. Реминисценции Н.В. Гоголя и Ф.М. Достоевского в рассказе Ю.В. Буйды «Карлик Карл» // Вестник Северо-Восточного федерального ун-та им. М.К. Аммосова. Якутск, 2019. №2(70). С. 103-111.

DOI: $10.25587 /$ SVFU.2019.70.28412

Скавыш B. «Мертвые души»: психопатологизация личности Гоголя - миф сциентизма // Невроньюс: Новости неврологии: [ежемесячная газета.] М., 2019. Вып. 11(61). Ноябрь. С. 6-8; продолжение: М., 2020. Вып. 1(63). Январь. С. 6-8; М., 2020. Вып. 3(65). Март. C. 13-14.

Скатов Н.Н. Избранные работы по русской литературе XIX века. СПб.: Изд-во РГПУ им. А.И. Герцена, 2019.

Из содерж:

«Человек и гражданин земли своей...» Н.В. Гоголь. С. 105-113.

Сквира H. «Не оживет, аще не умрет», или Зачем Гоголь сжег второй том «Мертвых душ»? // Русская народная линия. СПб., 2019. 06.02. (www.ruskline.ru).

Славутин Е.И., Пимонов В.И. Структура сюжета: сб. статей / Предисл. Е.В. Жаранова. 2-е изд., стер. М.: ФЛИНТА, 2019. 172 с. 200 экз.

Из содерж.:

Как все-таки сделана «Шинель» Гоголя? С. 124-135.

[Впервые: Известия Самарского научного центра Российской академии наук. Социальные, гуманитарные, медико-биологические науки. Самара, 2017. Т. 19. №3. С. 116-120.]

[1-е изд.: М.: ФЛИНТА, Наука, 2018.]

Сторожева A.A. «Степной» текст в прозе Н.В. Гоголя и А.П. Чехова: сопоставительный анализ // Вестник Рязанского гос. ун-та им. С.А. Есенина. Рязань, 2019. № 4(65). C. $142-152$. 
Сун Иньнань. Конфуций и Гоголь: диалог об искусстве через столетия // Litera. M., 2019. № 4. С. 221-227.

DOI: $10.25136 / 2409-8698.2019 .4 .30514$

Титова A. Первые постановки комедии Н.В. Гоголя «Ревизор»: причины неудач // Актуальная классика: Материалы Третьих студенческих научных чтений (Москва, 18 апреля 2019 г.). М.: Литера, 2019. С. 163-166.

Tuтова A.C. Прецедентное имя как диахроническая матрица (эволюция имени Плюшкин в коммуникативном сознании) // Научные ведомости Белгородского гос. ун-та. Серия Гуманитарные науки. Т. 38. № 4. Белгород, 2019. С. 532-539.

Трущелёв А.А. Гоголиана С.М. Романовича // Научные труды / Санкт-Петербургский гос. академический институт живописи, скульптуры и архитектуры им. И.Е. Репина. СПб., 2019. № 1. С. 153-176.

[На примере картины С.М. Романовича из собрания Радищевского музея (Саратов) «Гоголь среди своих персонажей» рассматриваются художественно-стилистические особенности гоголевского цикла художника.]

Tюna В.И. Пограничные состояния в литературном нарративе // Вестник РГГУ. Серия Литературоведение. Языкознание. Культурология. М.: Российский гос. гуманитарный ун-т, 2019. № 2. С. 10-18.

[Зарождение абсурдной нарративности в петербургских повестях Гоголя: С. 16-17.]

Славянский мир: духовные традиции и словесность: сб. материалов международной научной конференции (Тамбов, 23-25 мая 2019 г.). Вып. 9 / Тамбовский гос. ун-т им. Г.Р. Державина [и др.]; науч. ред. Н.Ю. Желтова. Тамбов: Принт-Сервис, 2019. 624 с.

Из содерж.:

Гл. 1: Дискурс святого Кирилла и Н.В. Гоголя в художественном сознании славянских писателей. Горланов Г.Е. О Н.В. Гоголе как писателе национальном: повесть «Тарас Бульба». С. 66-73.

Олджай T. Николай Гоголь: личность и наследие в Турции (к 210-летию писателя). С. 73-81.

Оляндэр Л.К. Поэтика Николая Гоголя: структура и нарративная организация текста в повести Любена Каравелова «Българи от старо време» («Болгары старого времени», 1872). С. 81-92.

Шолак 3. Николай Гоголь, Иво Андрич и другие южнославянские писатели: обзор элементов техники повествования. С. 93-107.

Ян Лиюнь. Языковые особенности творчества Н.В. Гоголя. С. 112-118.

Фенчук О.Н. Духовная связь между предками и потомками в произведениях Н.В. Гоголя. С. 118-123. [Традиции Запорожского казачества в произведениях Гоголя.]

Грудинина Е.В. Повесть Н.В. Гоголя «Вий»: духовный смысл и современное прочтение. С. 123-133. [Сравнительный анализ киноверсий повести, созданных во второй половине XX - начале XXI в.] Талалаева О.Г. Гоголевские традиции в «готической» прозе И.А. Бунина. С. 134-139.

Сазонова Н.С. Гоголевские мотивы в цикле М. Горького «По Руси». С. 139-143.

Терехова И.Н. Творческая личность Н.В. Гоголя в эмигрантском журнале «Современные записки». С. $143-147$.

[Очерк Б.К. Зайцева «Жизнь с Гоголем».]

Павлова В.В., Фролова И.И. Сравнение как средство создания комического в поэме Н.В. Гоголя «Мертвые души». С. 147-152.

Гл. 2: Славянские культурные ценности и русская литература XX-XXI веков

Лебедева В.Ю. Отсветы гоголевской «демонской лампы» в ранней прозе Е. Замятина и В. Набокова. С. 225-230.

Советский «Вий» - в сотне самых страшных фильмов // Комсомольская правда. М., 2019. 18 октября. №232(432). С. 2.

[Советский фильм ужасов «Вий», снятый в 1967 г. по одноименной повести Гоголя, вошел в список лучших фильмов ужасов по версии портала Indiewire. Картина заняла 89-е место. Ранее «Вий» попал в список лучших хорроров по версии авторитетного профильного сайта Bioody Disqusting.] 
Суровиева E.B. Творчество Н.В. Гоголя в мировом кинематографе // Исследователь года 2019: сб. статей международного научно-исследовательского конкурса (Петрозаводск, 12 мая 2019 г.). Петрозаводск, 2019. С. 75-83.

«Таинство слова и образа»: К 1030-летию Крещения Руси: сб. материалов научно-богословской конференции (Сергиев Посад, 3-4 октября 2018 г.) / Московская Духовная академия, кафедра филологии; редкол.: проф. В.М. Кириллин, свящ. Дмитрий Барицкий (отв. ред.), иером. Далмат (Юдин). Сергиев Посад; Переславль: Изд-во Московской Духовной академии; Издательский отдел Переславской епархии, 2019. 448 с.: ил. 150 экз.

Из содерж: :

Захарченко С.О. Отеческое слово преподобного Макария Оптинского. С. 152-169.

Паломничество к святым мощам. С. 161, 162, 163.

[Рассказ Гоголя о чуде у мощей святителя Спиридона Тримифунтского на Корфу, пересказанный старцем Макарием в письме к духовной дочери Анне Ивановне Воейковой. Приложено факсимиле письма.]

Бурмистрова С.В. Аллюзии на апостольский текст в «Записках сумасшедшего» Н.В. Гоголя. C. $254-263$.

Bоропаев B.A. «Размышления о Божественной Литургии» Н.В. Гоголя в свете святоотеческой традиции. С. 264-279.

Титова A. Первые постановки комедии Н.В. Гоголя «Ревизор»: причины неудач // Актуальная классика: Материалы Третьих студенческих научных чтений (Москва, 18 апреля 2019 г.). М.: Литера, 2019. С. 163-166.

Тихомиров В.В. И.С. Аксаков - литературный критик // Вестник Костромского гос. унта. Кострома, 2019. Т. 25. № 4. С. 88-94.

DOI 10.34216/1998-0817-2019-25-4-88-94

[В частности, о некрологической статье И.С. Аксакова «Несколько слов о Гоголе» (1852).]

Трегубов А. 210 лет загадок Гоголя // Московский комсомолец. М., 2019. 1 апреля. № 68(27.940). C. 4.

Тумгоева М.И. Мотив безумия в творчестве Н.В. Гоголя и М.А. Булгакова // Colloquiumjournal. Голая пристань (Варшава), 2019. № 2-3(26). С. 67-68.

[На материале повести Гоголя «Портрет» и романа М.А. Булгакова «Мастер и Маргарита».]

Уроки литературы. Приложение к журналу «Литература в школе». М., 2019. № 3.

Из содерж.:

Золотусский И.П. Слово о Гоголе. С. 1-6.

Румянцев А.Г. «К нам едет ревизор...». С. 7-12.

Подгрушная О.С. Изучение повести Н.В. Гоголя «Майская ночь, или Утопленница». С. 12-14. Кучина Е.С. Духовно-нравственная основа повести Н.В. Гоголя «Вий: методические рекомендации к изучению произведения: VI-VII классы. С. 14-16.

Урюпин И.С. Мифологема житейского моря и морская образность в комедии М.А. Булгакова по поэме Н.В. Гоголя «Мертвые души» // Acta Eruditorum / Русская христианская гуманитарная академия. СПб., 2019. № 32. С. 75-78.

DOI: 10.25991/AE.2019.58.61.012

Фадеев К.Н. Характеры, конфликт рассказов «Шинель» Н.В. Гоголя и «Бататовая каша» Акутагавы Рюноскэ // Наука XXI века: открытия, инновации, технологии: сб. научных трудов по материалам $\mathrm{V}$ международной научно-практической конференции (Смоленск, 1 июля 2019 г.) / Международный научно-информационный центр «Наукосфера». Смоленск, 2019. С. 77-81.

Фокеев А.Л. «Этнографический романтизм» раннего творчества Н.В. Гоголя // Литература. Театр. Слово. Духовно-эстетический опыт эпохи: Материалы всероссийской научно-практической конференции (Самара, 17 мая 2019 г.) / Самарское региональное 
общественное учреждение «Центр духовно-нравственного воспитания «Слово», «Научно-технический центр»; редкол.: Н.С. Филатова, Э.А. Радаева. Самара, 2019. С. 154-161. [На материале «Вечеров на хуторе близ Диканьки» Гоголя.]

Чега В.А. Вий как ключевая мифологема повести Н.В. Гоголя «Вий» // Linguistica Juvenis: сб. научных трудов молодых ученых / Уральский гос. педагогический ун-т. Екатеринбург, 2019. №21. С. 142-150.

Чега В.А. Реминисценция образа Вия Н.В. Гоголя в творчестве А.М. Ремизова и О.Э. Мандельштама // Актуальные проблемы филологии / Уральский гос. педагогический ун-т. Екатеринбург, 2019. № 19. С. 182-187.

Черепенникова М.С. Итальянские путешествия Гете и Гоголя. интертекстуальные параллели (к 270-летию Гете и 210-летию Гоголя) // Филология и человек / Алтайский гос. ун-т. Барнаул, 2019. № 2. С. 7-20.

DOI 10.14258/filichel(2019)2-01

Черных E. Проклятие классика: обреченный на нищету Гоголь просил деньги у царя, а сюжеты клянчил у коллег // Комсомольская правда. М., 2019. 28 марта - 4 апреля. С. 44-45. [1 апреля - 210 лет со дня рождения самого загадочного русского писателя, чьи жизнь и смерть до сих пор окутаны тайной.]

Чернышев Д.Б., Щербак Н.М. Религия как маркер самоопределения человека на примере повести Н.В. Гоголя «Тарас Бульба» // Современная наука: актуальные вопросы, достижения и инновации: сб. статей VII международной научно-практической конференции (Пенза, 5 июня 2019 г.): В 4 ч. Ч. 1 / Международный центр научного сотрудничества «Наука и просвещение»; отв. ред. Г.Ю. Гуляев. Пенза, 2019. С. 233-235.

Четверикова А. Помещик Плюшкин - профессор Погодин: пародия по-гоголевски // Родина. М., 2019. № 9. С. 32-35.

[М.П. Погодин как прототип Плюшкина в «Мертвых душах» Гоголя.]

Юрченко Т.Г. [Реферат] // Социальные и гуманитарные науки. Отечественная и зарубежная литература. Серия 7. Литературоведение. Реферативный журнал / Институт научной информации по общественным наукам РАН. М., 2019. № 4. С. 112-115.

[Реф. кн.: Дубровская С.A. «От Арзамаса» до Гоголя: смеховое слово в пространстве русской литературы 1810-х - начала 1840-х гг.: монография / Науч. ред. О.Е. Осовский. Саранск: Изд-во Мордовского ун-та, 2018. 252 с.]

Шевырев С.П. Полное собрание литературно-критических трудов: В 7 т. Т. 1: (1823-1830) / Сост. и общ. ред. А.Н. Николюкина; вступ. статья А.М. Ранчина; подгот. текста М.А. Бирюковой и И.В. Логвиновой; коммент А.Н. Николюкина, Н.В. Цветковой / Институт научной информации по общественным наукам РАН. СПб.: Изд-во «Росток», 2019. 656 с. 300 экз.

Загл. вступ. статьи: С.П. Шевырев: у истоков русского литературоведения. С. 10-62.

[С.П. Шевырев о Гоголе. С. 41-44.]

Шишкин А.Е. «Прокуроры» и «адвокаты» Н.В. Гоголя // Литература. Театр. Слово. Духовно-эстетический опыт эпохи: Материалы всероссийской научно-практической конференции (Самара, 17 мая 2019 г.) / Самарское региональное общественное учреждение «Центр духовно-нравственного воспитания «Слово», «Научно-технический центр»; редкол.: Н.С. Филатова, Э.А. Радаева. Самара, 2019. С. 222-238.

Штильман С.Л. От заглавия до последней строки. Учимся читать классику: Пособие для учителей и учащихся. 2-е изд., доп. и испр. М.: Изд-во Московского ун-та, 2019. 363 с. - (Школа вдумчивого чтения).

Ч. 2: Статьи о творчестве Николая Васильевича Гоголя.

Под маской гротеска (О специфике гоголевского «реализма»). С. 121-134.

Герой нашего времени. Чичиков (Попытка лирического отступления). С. 134-143.

Перечитывая Ивана Александровича Гончарова. 
«Книга отражений». «Обломов» (Гоголевские мотивы в романе И.А. Гончарова). С. 144-152.

Статьи о творчестве Антона Павловича Чехова.

«Мертвые души» в творчестве А.П. Чехова. С. 256-265.

Ч. 3: «Говорящие» имена в русской драме. Попытка систематизации. С. 321-332.

[«Ревизор», «Игроки» Гоголя. С. 326-327]

Штридтер Ю. Плутовской роман в России: к истории русского романа до Гоголя / Пер. с нем. В. Брун-Цехового, Д. Бордюгова. М.; СПб.: АИРО-ХХІ; Алетейя, 2015. 413 с. (Серия АИРО - первая публикация в России).

[Указ. имен.]

[Впервые: Striedter J. Der Schelmenroman in Russland. Ein Beitrag zur Geschichte des russischen Romans vor Gogol.Berlin, 1961.]

Шульи С.А. К исторической поэтике русской сатиры: А.Н. Радищев, И.А. Крылов, А.С. Грибоедов, Н.В. Гоголь // Литературоведческий журнал / Институт научной информации по общественным наукам РАН. М., 2019. № 46. С. 26-38.

Шульи С.А. Пушкин, Гоголь, Блок (от «Пиковой дамы» к «Вию» и «Стихам о Прекрасной Даме») // Болдинские чтения: доклады международной научной конференции (Болдино, 17-21 сентября 2018 г.) / Гос. литературно-мемориальный и природный музей-заповедник А.С. Пушкина «Болдино; отв. ред. И.С. Юхнова. Нижний Новгород: Национальный исследовательский Нижегородский гос. ун-т им. Н.И. Лобачевского, 2019. С. 146-155.

Яньцюю Чжан. Лексические средства передачи эмоции страх в произведениях Н.В. Гоголя и их китайские аналоги // Современная наука: Актуальные проблемы теории и практики. Серия: Гуманитарные науки. М., 2019. № 5(2). С. 188-192.

Яхияева C.X. Гоголевские традиции в творчестве М. Зощенко (на материале произведений Н. Гоголя «Невский проспект» и М. Зощенко «Свадьба») (из опыта работы) // Русский язык и литература в школе и вузе: научно-методический сб. (с международным участием) памяти Г.Н. Сивриди / Под ред. К.Э. Джамалова, Т.И. Магомедовой, М.Д. Ваджибова, С.Ю. Веровой. Вып. 8. Махачкала: АЛЕФ, 2019. С. 90-91.

Яхонтов А. Может ли театр совсем без женщин? // Московский комсомолец. М., 2019. 7 декабря. № 273(28.145). С. 5.

[В Малом театре поставили пьесу Гоголя «Игроки» (режиссер Владимир Драгунов), которая не предусматривает женских ролей.]

Яхонтов А. Новая шинель Акакия Акакиевича: рассказ // Московский комсомолец. М., 2019. 30 марта. № 67(27.939). С. 5.

\section{АВ Т О РЕФЕ РАТ Ы}

Долгушин Д.В. В.А. Жуковский и религиозно-философская культура его времени: Автореф. дисс. ... д-ра филол. наук / Новосибирский национальный гос. ун-т. Томск, 2019. 39 с.

2.3.3: «Христианская философия» в поэме «Странствующий жид»

C. 25: Тема покаяния в поэме - «одна из точек сближения Жуковского с Н.В. Гоголем, который, как известно, во втором томе «Мертвых душ» также хотел привести своих героев, в том числе и Чичикова, к перемене. Характерно, в связи с этим, почти одновременное внимание Жуковского и Гоголя к имени «Павел»: Гоголь дает это имя главному герою своей поэмы, а Жуковский своему сыну. В творческом сознании и того, и другого оно соотносится с апостолом Павлом, жизнь которого может рассматриваться как своего рода архетип покаяния».

Дубровская С.А. Смеховое слово в русском литературном сознании 1810-х - начала 1840-х гг.: Автореф. дисс.... д-ра филол. наук / Мордовский гос. ун-т им. Н.П. Огарева. Казань, 2019. 41 с.

Гл. 1: Смех и смеховое слово как литературоведческая проблема: теоретико и историко-литературный аспекты. 
1.3: Бахтинский «сюжет о Гоголе и Рабле» в работах отечественных исследователей. С. 16-18. Гл. 6: Смех и смеховое слово Н.В. Гоголя

6.1: Особенности функционирования смехового слова в «Вечерах на хуторе близ Диканьки». C. $30-31$.

6.2: «Романтически окрашенное» смеховое слова повестей Гоголя. С. 31.

[«Миргород», петербургские повести.]

6.3: Смех и сатира в комедийном дискурсе. С. 31-32.

[«Ревизор», «Женитьба», «Игроки».]

6.4: Смеховое начало поэмы «Мертвые души». С. 32-33.

6.5: Специфика смехового слова в эпистолярии писателя. С. 33-34.

Меладшина Ю.В. Гоголевский текст в романе В.А. Шарова «Возвращение в Египет. Выбранные места из переписки Николая Васильевича Гоголя (Второго)»: Автореф. дисс.... канд. филол. наук / Уральский гос. пед. ун-т. Екатеринбург, 2019. 18 с.

Овчинников Д.П. Малороссийский текст в творчестве Н.В. Гоголя: Автореф. дисс.... канд. филол. наук / Шуйский филиал Ивановского гос. ун-та. Симферополь, 2019. 23 с.

Яньц̧ю Чжан. Языковые средства передачи эмоций в прозе писателей XIX века: на материале повестей А.С. Пушкина, М.Ю. Лермонтова и Н.В. Гоголя: Автореферат дисс.... канд. филол. наук / Санкт-Петербургский гос. ун-т. Великий Новгород, 2019. 27 с.

Сведения об авторе-составителе:

Владимир Алексеевич Воропаев, доктор филол. наук

профессор

филологический факультет

МГУ имени М.В. Ломоносова
Vladimir A. Voropaev,

Doctor of Philology

Professor

Philological Faculty

Lomonosov Moscow State University

voropaevvl@bk.ru 